\title{
Advances in Small-Cell Lung Cancer (SCLC) Translational Research
}

\author{
Benjamin J. Drapkin ${ }^{1}$ and Charles M. Rudin ${ }^{2}$ \\ ${ }^{1}$ University of Texas Southwestern Medical Center, Dallas, Texas 75390, USA \\ ${ }^{2}$ Memorial Sloan Kettering Cancer Center, New York, New York 10065, USA \\ Correspondence: rudinc@mskcc.org
}

Over the past several years, we have witnessed a resurgence of interest in the biology and therapeutic vulnerabilities of small-cell lung cancer (SCLC). This has been driven in part through the development of a more extensive array of representative models of disease, including a diverse variety of genetically engineered mouse models and human tumor xenografts. Herein, we review recent progress in SCLC model development, and consider some of the particularly active avenues of translational research in SCLC, including interrogation of intratumoral heterogeneity, insights into the cell of origin and oncogenic drivers, mechanisms of chemoresistance, and new therapeutic opportunities including biomarker-directed targeted therapies and immunotherapies. Whereas SCLC remains a highly lethal disease, these new avenues of translational research, bringing together mechanism-based preclinical and clinical research, offer new hope for patients with SCLC.

S mall-cell lung cancer (SCLC) afflicts approxSimately 30,000 patients per year in the United States and carries a 5-year overall survival rate of $6 \%$ (American Cancer Society 2020). Because of early and rapid metastasis, SCLC patients rarely benefit from surgery, and responses to chemotherapy and radiation are typically brief. In contrast to non-small-cell lung cancer (NSCLC), in which genotype-directed therapies have dramatically improved treatment outcomes for thousands of patients, there are no clear kinase targets in SCLC, no approved targeted therapies (Shtivelman et al. 2014; Byers and Rudin 2015), and the repurposing of existing drugs has failed to demonstrate meaningful clinical impact (Kalemkerian 2014). Thus, there is a critical need for identification of novel therapeutic targets and strategies in SCLC. Indeed, SCLC was designated a "recalcitrant cancer" by the National Cancer Institute (NCI) under the Recalcitrant Cancer Research Act (RCRA) of 2013, highlighting the urgency for development of improved preclinical models and therapeutic strategies in this disease.

Although SCLC has been viewed as a monolithic disease with a grim prognosis, this is poised to change thanks to the rapid expansion in research following passage of the RCRA. The purpose of this review is to highlight the advances in six areas of SCLC research:

1. Development of new patient-derived models;

2. SCLC genomic landscapes and oncogenic insights from mouse models;

Editors: Christine M. Lovly, David P. Carbone, and John D. Minna

Additional Perspectives on Lung Cancer: Disease Biology and Its Potential for Clinical Translation available at www.perspectivesinmedicine.org

Copyright (C) 2021 Cold Spring Harbor Laboratory Press; all rights reserved; doi: 10.1101/cshperspect.a038240

Cite this article as Cold Spring Harb Perspect Med 2021;11:a038240 
B.J. Drapkin and C.M. Rudin

3. Investigation of intratumoral heterogeneity;

4. Cell of origin and mechanism of transdifferentiation from adenocarcinoma;

5. Chemoresistance and DNA damage repair; and

6. Immune evasion and immunotherapy.

\section{EXPANSION OF HUMAN DISEASE MODELS FROM BIOPSIES AND CIRCULATING TUMOR CELLS}

The basic properties of SCLC growth were elucidated from panels of cell lines developed from 1971 through the early 1990s (Oboshi et al. 1971; Carney et al. 1980; Pettengill et al. 1980; Baillie-Johnson et al. 1985). The largest of these efforts comprised 122 SCLC lines derived from patients treated at the NCI-Department of Vet- erans Affairs (VA) and NCI Navy Medical Oncology Branches during this time frame (Gazdar and Minna 1996). These cell lines have been distributed globally, and their molecular and clinical features have been extensively annotated. They remain the primary resource for studying this disease.

Questions tied to specific clinical outcomes, such as chemoresistance following relapse, require model fidelity to a relevant clinical history (Fig. 1). Although the clinical histories associated with the NCI series of SCLC cell lines were carefully annotated, staging technology and drug regimens have changed significantly since the 1980s. Only nine NCI cell lines were derived following platinum plus etoposide, while the majority were derived from patients who received cyclophosphamide-based regimens (Johnson et al. 1996). Furthermore, the molec-

Cell line xenograft

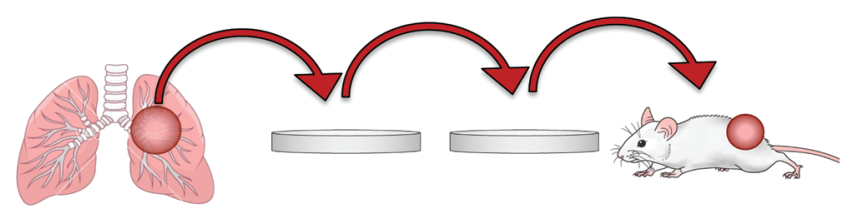

Genetically engineered mouse model (GEMM)
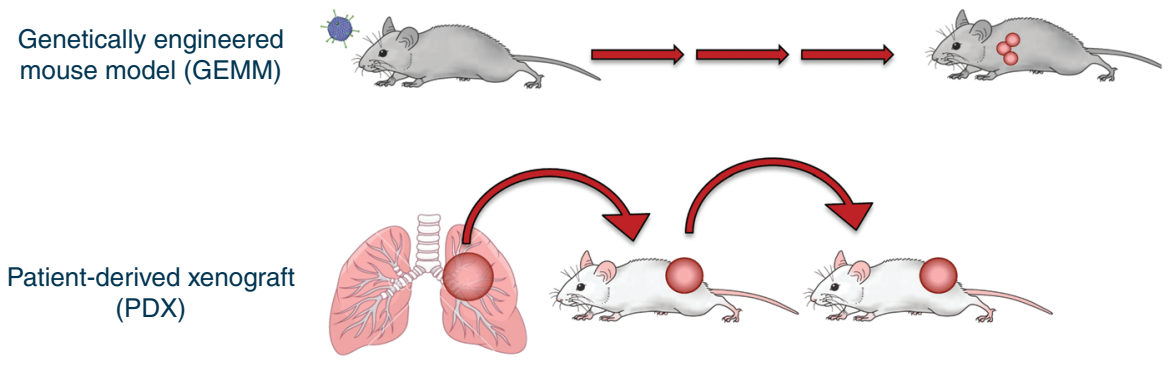

Circulating tumor cell-line-derived xenograft (CDX)

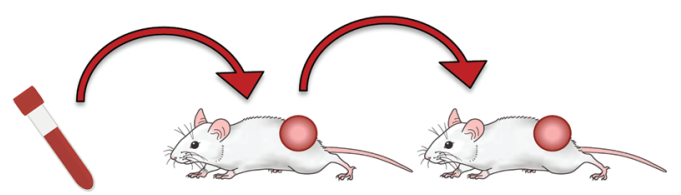

Figure 1. Frequently used in vivo models of small-cell lung cancer (SCLC). Cell-line-derived xenografts (CDXs) have been a mainstay of SCLC research for many years. These have advantages including speed, number of available models, and ease of use. Genetically engineered mouse models have greatly expanded in number and complexity. These have advantages including immunocompetence, in situ oncogenesis, and ability to definitively test the role of individual drivers. The number of available patient-derived xenograft (PDX) and CDX models is also rapidly increasing in laboratories around the world. These have advantages including genetic and epigenetic proximity to human disease, heterogeneity, and links to individual patient outcomes. An additional advantage of CDX is the broad availability of blood as a source for model generation. 
ular features that distinguish clinical outcomes, such as correlation between in vitro chemosensitivity and whether the line was derived from an untreated or postrelapse patient, were not consistently retained (Polley et al. 2016). In addressing current clinical questions, it is particularly useful to have high-fidelity models from current or recent patients.

Patient-derived xenograft (PDX) models are generated via the direct implantation of tumor material, usually from surgical resections, biopsies, or effusions, into immunocompromised mice with no intermediate in vitro culture (Hidalgo et al. 2014; Aparicio et al. 2015). Clinical development of $\mathrm{BH} 3$ mimetics exemplifies their utility as preclinical models of SCLC. BCL2/ BCLxL inhibitors showed dramatic efficacy in a series of SCLC cell-line models both in vitro and in vivo (Oltersdorf et al. 2005; Shoemaker et al. 2008). In contrast, SCLC PDX models generally demonstrate minimal single-agent sensitivity to the BCL2/BCLxL inhibitor ABT-737 (Hann et al. 2008). Entirely in keeping with the PDX result, a phase II clinical study of navitoclax, a related compound, in relapsed SCLC patients showed only one partial response in 39 patients (Rudin et al. 2012a). Artifacts of in vitro selection may underlie this difference in clinical fidelity, as marked and irreversible changes in gene expression have been observed during cellline derivation from SCLC PDX models (Daniel et al. 2009). These studies suggest that PDX models might better recapitulate the expression profiles and drug sensitivities of SCLC patient tumors than xenografts from established cell lines.

Historically, generation of SCLC PDX models has been hindered by scarcity of viable tumor samples. SCLC is almost never surgically resected, and invasive tumor sampling is usually not clinically indicated following diagnosis. Circulating tumor cells (CTCs) can be sampled noninvasively (Yu et al. 2011, 2013; Haber and Velculescu 2014), and are highly abundant in SCLC patients (Bevilacqua et al. 2009; Hou et al. 2009, 2012; Naito et al. 2012). Change in CTC number correlates closely with response to chemotherapy, suggesting that CTCs mirror SCLC tumor biology. However, isolation tech- nologies often rely on either chemical fixation, which would render CTCs nonviable, or positive enrichment by EpCAM expression, which would exclude nonepithelial CTCs (Calbo et al. 2011; Yu et al. 2014). Enrichment of live unmanipulated SCLC CTCs was first accomplished by depletion of nonmalignant nucleated cells with an antileukocyte antibody cocktail, and for SCLC patients with high tumor burdens, these CTC-enriched blood products yielded PDX models with high efficiency (Hodgkinson et al. 2014). CTC-derived PDX models were histologically similar to patient tumors, and copy number alterations in the models mirrored the parent CTCs. A similar approach using a microfluidicbased live CTC capture platform, the CTC-iChip (Ozkumur et al. 2013; Karabacak et al. 2014), was used to generate a large cohort of PDX models with high efficiency (35\% per blood draw) (Drapkin et al. 2018). In contrast with established SCLC cell lines (Polley et al. 2016), PDX sensitivity to first-line cisplatin/etoposide (EP) was strongly correlated with observed tumor response in the corresponding patient (Drapkin et al. 2018), suggesting that these models had sufficient clinical fidelity to study chemoresistance.

Scarcity of clinical samples was previously an obstacle to PDX establishment, but this has been overcome by development of new techniques, and recognition of the capacity of even small numbers of SCLC cells to engraft in foreign environments. At least 66 PDX models of SCLC have been reported (Némati et al. 2010; Saunders et al. 2015; Gardner et al. 2017; Drapkin et al. 2018; Lallo et al. 2018), and many more have been established. Their molecular and functional fidelity to the originating patient's disease makes them important tools for preclinical testing. However, PDX models have significant limitations, most notably: (1) they are inherently low throughput, as short-term cultures still require an originating xenograft (Lallo et al. 2019); (2) they are difficult to manipulate genetically, although a recently reported CRISPR-Cas9 system in NSCLC PDX models offers a strategy to address this obstacle (Hulton et al. 2020); (3) they require a severely immunosuppressed microenvironment to grow; and (4) 
their clinical relevance may decline over time as management of SCLC advances. The standard of care first-line therapy in the United States is now EP + atezolizumab (Horn et al. 2018). No models have yet been reported that represent relapse following durable response to this regimen, and the immune checkpoint blockade will be a challenge to study without development of at least partially immunocompetent PDX models.

\section{SCLC GENOMIC LANDSCAPES AND ONCOGENIC INSIGHTS FROM MOUSE MODELS}

The genomic hallmarks of SCLC, biallelic loss of $R B 1$ and TP53, are so prevalent within the disease that they cannot define subclasses, and drugs have not been developed to target the absence of either tumor suppressor. Recent genomic profiles of primary patient samples have revealed additional recurrent alterations. These have been recapitulated using genetically engineered mouse models (GEMMs) to assess functional significance, with the ultimate goal of developing subtype-specific targeted therapies.

\section{Genomics}

The first SCLC genome, reported in 2010, identified a mutation signature associated with tobacco smoking in the cell line NCI-H209 (Pleasance et al. 2010). This was rapidly followed by two whole-exome sequencing studies, representing 36 and 29 patients, respectively (Peifer et al. 2012; Rudin et al. 2012b). The largest effort to date scoured global tissue repositories to obtain 110 fresh-frozen samples suitable for whole-genome sequencing (George et al. 2015). For these studies, tumor samples were obtained almost exclusively from untreated patients and enriched for early-stage disease.

Loss of RB1 and TP53 were first identified as common recurrent alterations in SCLC in established cell lines (Harbour et al. 1988; Hensel et al. 1990, 1991), and this has been confirmed in genome-sequencing studies of primary tumors. Whole genome sequencing revealed universal biallelic inactivation of TP53 (110/110 cases), and loss of $R B 1$ was more common than previously reported (108/110 cases) due to detection of complex genomic rearrangements (George et al. 2015). The two exceptional $R B 1^{W T}$ cases harbored chromothripsis events that resulted in massive overexpression of cyclin $\mathrm{D} 1$, underscoring the requirement for RB inactivation in SCLC. Recurrent mutations were identified in the RB-related tumor suppressors RBL1 (p107) and RBL2 (p130), both of which can also bind E2F transcription factors (Cao et al. 1992; Dyson et al. 1992; Cobrinik et al. 1993; Schwarz et al. 1993).

In addition to loss of $R B 1$ and TP53, genome sequencing revealed recurrent amplification of $B C L 2$ and the MYC family of proto-oncogenes (MYC, MYCL1, and MYCN) and loss of the tumor suppressor PTEN in a small but significant fraction of cases (Peifer et al. 2012; Rudin et al. 2012b; George et al. 2015). Although these genomic features had been previously described in cell lines (Little et al. 1983; Nau et al. 1985, 1986; Ikegaki et al. 1994; Kim et al. 1998; Olejniczak et al. 2007), their prevalence in primary samples had not been evaluated. New recurrent alterations were identified in the histone-modifying enzymes CREBBP, EP300, and $M L L$, amplifications of SOX2 and FGFR1, amino-terminal dominant-negative truncations in TP73 (Jost et al. 1997; Flores et al. 2002; Stiewe et al. 2002), and mutually exclusive inactivating mutations in the extracellular domains of NOTCH receptors. The functional significance of these recurrent genomic alterations has been established primarily through conditional knockout or expression in autochthonous mouse models (murine SCLC [mSCLC]).

\section{RBL2 (p130), PTEN, and NFIB}

The original mSCLC model carried conditional homozygous knockout alleles of $R b 1$ and Trp53 $\left(R b 1^{f / f} ; \operatorname{Trp5} 3^{f / f}\right.$, herein " $R P$ ”), and tumors were generated in lung epithelial cells by intratracheal instillation of Adeno-Cre (Meuwissen et al. 2003). These mice develop dysplastic precancerous lesions that slowly progress to mSCLC over 10-15 months, and expression of a single wildtype allele of either $R b 1$ or $\operatorname{Trp} 53$ results instead 
in adenocarcinoma formation after 1-2 years. During the long latency, $R P$ tumors can acquire $\mathrm{Mycl}$ or Nfib amplifications, or Pten loss (Calbo et al. 2005, 2011; Dooley et al. 2011; McFadden et al. 2014). All three alterations are recurrent in human SCLC, with NFIB expression enhanced in metastatic lesions (Denny et al. 2016). Additional knockout of either Rbl2 ( p130) or Pten, or constitutive expression of $N f i b$, within the $R P$ background accelerates mSCLC tumorigenesis significantly (Schaffer et al. 2010; Cui et al. 2014; Wu et al. 2016), with RP-Pten tumors containing mixed adenocarcinoma components (Gazdar et al. 2015). These experiments demonstrated tumor-suppressor functions for $p 130$ and Pten and an oncogenic function for N $f i b$ in $\mathrm{mSCLC}$.

\section{MYCL and MYC}

SCLC tumors harbor recurrent amplifications of $M Y C, M Y C L$, or $M Y C N$, as well as inactivating mutations in MYC-regulatory factors $M A X$, $M G A$, and BRG1 (Romero et al. 2014). Although these alterations are mutually exclusive, implying some redundancy, they result in tumors with distinct morphologies, expression profiles, and gene dependencies. Constitutive expression of Mycl1 in the RP background accelerates mSCLC growth (Kim et al. 2016), resulting in tumors with a "classic" SCLC morphology first identified in cell-line-derived xenografts: small round cells with scant cytoplasm, fine granular chromatin, and indistinct nucleoli (Gazdar et al. $1985,2015)$. In contrast, expression of a stabilized $M y c$ allele $\left(M y c^{T 58 A}\right)$ results in highly aggressive mSCLC with variant morphology similar to $M Y C$-amplified human SCLC, including reduced expression of neuroendocrine (NE) markers (Mollaoglu et al. 2017) and increased dependence on both Aurora kinase (Hook et al. 2012; Sos et al. 2012) and arginine biosynthesis (Chalishazar et al. 2019).

\section{CREBBP}

Conditional knockout of Crebbp in the RP background (RP-Crebbp) also accelerated mSCLC tumorigenesis (Jia et al. 2018). Although $R P$ -
Crebbp tumors have classic SCLC histology, loss of histone acetyltransferase (HAT) activity leaves histone deacetylases (HDACs) unopposed, leading to partial epithelial-to-mesenchymal transition (EMT). Treatment with HDAC inhibitors reversed this effect and caused $R P$-Crebbp regression.

\section{ASCL1, NEUROD1, NOTCH, and POU2F3}

ASCL1 and NEUROD1, two basic-loop-helix transcription factors with roles in neuronal development, are differentially expressed in SCLC cell lines and act as essential, lineage-defining oncogenes (Guillemot et al. 1993; Yasunami et al. 1996; Borges et al. 1997; Osada et al. 2005; Jiang et al. 2009; Osborne et al. 2013; Augustyn et al. 2014; Borromeo et al. 2016). ASCL $1^{\text {high }}$ lines and xenografts demonstrate classic morphology, high NE expression, and frequent MYCL amplification, whereas NEUROD1 $1^{\text {high }}$ SCLC demonstrates variant morphology, MYC amplification, and selective tropism for the oncolytic Seneca Valley Virus (Carney et al. 1985; Gazdar et al. 1985; Poirier et al. 2013; Borromeo et al. 2016). RP-p130 mSCLC is dependent on Ascl1 but not Neurod1 (Borromeo et al. 2016), whereas RP-Myc ${ }^{T 58 A}$ tumors preferentially express Neurod1 (Mollaoglu et al. 2017). During neuronal development, NOTCH represses ASCL1 to restrict progenitor differentiation (Meredith and Johnson 2000; Sriuranpong et al. 2002), and in lung development NOTCH suppresses both NE differentiation and expression of ASCL1 and NEUROD1 (Chen et al. 1997; Ito et al. 2000). Primary SCLC tumors reflect this relationship, as ASCL1 expression correlates with $D L K 1$, an inhibitory $\mathrm{NOTCH}$ ligand (George et al. 2015). In the $R P$-p130 model, expression of the NOTCH intracellular domain (NICD) delays tumorigenesis, directly demonstrating tumor-suppressor function. An inhibitor of the histone demethylase LSD1 has shown selective activity in SCLC models, and acts through NOTCH reactivation and repression of ASCL1 (Augert et al. 2019).

A subset of SCLC lacks expression of either ASCL1 or NEUROD1 (George et al. 2015; Borromeo et al. 2016), and some of these double- 
negative tumors are highly dependent on $P O U 2 F 3$, a transcription factor required for chemosensory tuft-cell development (Huang et al. 2018). POU2F3 $3^{\text {high }}$ SCLC tumors lack typical NE markers, and their divergent expression profile and gene dependencies suggest that this subtype may arise from a distinct cell of origin. A classification scheme for SCLC has been proposed based on dominant expression of one of four transcriptional regulators: ASCL1, NEUROD1, POU2F3, and YAP1 (Rudin et al. 2019). Prospective evaluation of these classes to predict responses to therapy may pave the way for subtype-specific clinical interventions.

\section{Need for More Genomic Sequencing}

Although significant progress has been made, there may be important recurrent genomic alterations in SCLC yet to be discovered. After $R B 1$ and TP53, no recurrent alterations have been reported in more than $25 \%$ of SCLC, with the majority present in $2 \%-10 \%$ of the population (Peifer et al. 2012; Rudin et al. 2012a; Umemura et al. 2014; George et al. 2015; Iwakawa et al. 2015; Sundaresan et al. 2017). Given a somatic mutation burden of $\sim 10$ per $\mathrm{Mb}, \sim 900$ samples would be required to saturate for mutations with $5 \%$ recurrence, and more than 3000 samples to saturate at 2\% (Lawrence et al. 2014). The largest genome-sequencing study published to date encompasses 110 samples, which may not fully saturate for mutations with $30 \%$ recurrence. To accumulate this, many samples will likely require routine CTC collection and expansion, or the advent of clinical rebiopsy, as in NSCLC.

\section{FLOATERS, STICKERS, AND INTRATUMORAL HETEROGENEITY}

Despite clonality, most tumors harbor significant cellular heterogeneity, which has been implicated in tumorigenesis, metastasis, and therapeutic resistance. Challenges in assessing the roles and importance of intratumoral heterogeneity include distinguishing stochastic variation from recurrent subpopulations of clinical significance, and developing strategies to selectively target key subpopulations (Table 1).

\section{Floaters and Stickers}

The initial efforts at SCLC cell-line derivation revealed subpopulations within individual tumors that were not just molecularly but mechanically distinct (Carney et al. 1985; Gazdar et al. 1985). Cell lines grew as either suspension aggregates or adherent monolayers, and in some cases as mixtures of both floating and adherent cells (Carney et al. 1985). For mixed cell lines, subculturing of these components revealed that suspension cells expressed high levels of NE markers, whereas adherent cells were non-neuroendocrine (non-NE) (Doyle et al. 1990). In parallel, a study of clonally derived cell lines revealed antigenic heterogeneity that would regenerate upon expansion from a single cell (Fargion et al. 1986). These studies suggest that within individual SCLC tumors there are characteristic and heritable patterns of differentiation into subpopulations.

\section{NE versus Non-NE}

Since these early descriptions of intratumoral heterogeneity, several recurrent SCLC subpopulations have been described. Most distinguish $\mathrm{NE}$ and non-NE populations, but they may not all be mutually exclusive. In the $R P$ mSCLC GEMM, it was observed that single cells from the same tumor could give rise to either NE suspension or non-NE adherent mesenchymal cell lines that retained these morphologies upon expansion to xenografts (Calbo et al. 2011). However, co-culture increased proliferation in vitro, and mixed xenografts gave rise to metastases due to paracrine Fgf2 signaling from non-NE cells (Kwon et al. 2015). These mixing studies suggested that cooperativity between subpopulations is an essential feature of SCLC biology.

\section{$\mathrm{NOTCH}$}

Although genomic and functional studies suggest that NOTCH acts as a tumor suppressor (Sriuranpong et al. 2001; Wael et al. 2014; 
Small-Cell Lung Cancer Translational Research

Table 1. Recurrent subpopulations in small-cell lung cancer (SCLC)

\begin{tabular}{|c|c|c|c|c|c|}
\hline Functional phenotype & Cell type & $\begin{array}{l}\text { Neuroendocrine } \\
\text { expression }\end{array}$ & $\begin{array}{l}\text { In vitro } \\
\text { growth }\end{array}$ & $\begin{array}{l}\text { Molecular } \\
\text { phenotype }\end{array}$ & References \\
\hline $\begin{array}{l}\text { Tumor-propagating cells } \\
\text { (TPCs) }\end{array}$ & Epithelial & Positive & Suspension & $\mathrm{CD}_{4} 4^{-} \mathrm{Mycl1}^{+}$ & $\begin{array}{l}\text { Jahchan } \\
\text { et al. } 2016\end{array}$ \\
\hline $\begin{array}{l}\text { Paracrine proliferation, } \\
\text { chemoresistance }\end{array}$ & Epithelial & Negative & Adherent & $\mathrm{CD}_{4}{ }^{-} \mathrm{Notch}^{+}$ & Lim et al. 2017 \\
\hline $\begin{array}{l}\text { Paracrine } \\
\text { proliferation, metastasis }\end{array}$ & Mesenchymal & Negative & Adherent & $\mathrm{CD} 44^{+} \mathrm{Fgf}^{+}$ & $\begin{array}{l}\text { Calbo et al. 2011; } \\
\text { Kwon } \\
\text { et al. } 2015\end{array}$ \\
\hline $\begin{array}{l}\text { Vasculogenic mimicry, } \\
\text { chemoresistance }\end{array}$ & Epithelial & Negative & Unknown & $\begin{array}{l}\text { VE-cadherin }{ }^{+} \\
\mathrm{CD}^{-} 1^{-}\end{array}$ & $\begin{array}{l}\text { Williamson } \\
\text { et al. } 2016\end{array}$ \\
\hline
\end{tabular}

George et al. 2015), SCLC cell lines and tumors demonstrate variable but significant levels of NOTCH expression and activity (George et al. 2015; Kaur et al. 2016; Zhang et al. 2018). To investigate intratumoral heterogeneity of Notch signaling, the $R P-p 130$ GEMM was engineered with a single-cell reporter for Notch activity: GFP under control of the endogenous Hes1 promoter (Lim et al. 2017). Notch ${ }^{\text {active }}$ cells were adherent, slow-growing, and non-NE, but expressed epithelial rather than mesenchymal markers (Calbo et al. 2011). Rapidly proliferating NE cells in suspensions were Notch ${ }^{\text {inactive }}$ but could be irreversibly converted to the Notch $^{\text {active }}$ state by Notch ligand on neighboring cells. Mixing of the cell types increased survival, and Notch ${ }^{\text {active }}$ cells were relatively resistant to chemotherapy. These results suggest a second intratumoral cooperative relationship that promotes growth and chemoresistance, with Notch signaling inducing non-NE differentiation.

\section{Tumor-Propagating Cells}

Two subpopulations of non-NE cells have been described that established a favorable microenvironment for the NE majority. Within the NE cells, a CD24 ${ }^{\text {high }} \mathrm{CD} 44^{\text {low }} \mathrm{EpCAM}^{\text {high }}$ subpopulation was identified that was 100 -fold more efficient at tumorigenesis than other immunophenotypes (Jahchan et al. 2016). These tumorpropagating cells (TPCs) expressed high levels of $M y c l 1$, and although knockdown of Mycl1 did not significantly affect proliferation, it did reduce tumorigenicity.

\section{Vasculogenic Mimicry}

A fourth functional subpopulation was discovered in SCLC PDX models that expressed the endothelial marker VE-cadherin (Williamson et al. 2016). In these xenografts, vascular networks were negative for murine CD31, suggesting that they were tumor-derived. Vasculogenic mimicry (VM), in which cancer cells undergo endothelial differentiation to form neovasculature, was first reported in uveal melanoma and has since been identified in a variety of solid tumors (Maniotis et al. 1999; Hendrix et al. 2003; Seftor et al. 2012). In human SCLC tumors with $\mathrm{VM}^{+}$vasculature, knockdown of VE-cadherin impaired growth and increased sensitivity to chemotherapy.

\section{Subclonal Mutations}

Despite the high mutational burden in SCLC, estimates of intratumoral genomic heterogeneity have been surprisingly low (Imielinski et al. 2012; George et al. 2015). These estimates were corroborated by comparison of PDX model genomes with originating patient tumors, which were nearly superimposable whether derived from biopsies or CTCs (Drapkin et al. 2018). However, recent efforts to compare pretreatment and postrelapse samples of circulating tumor DNA (ctDNA) (Nong et al. 2018) or CTCs (Su et al. 2019) have suggested significant clonal heterogeneity and emergence of genomically distinct subclones with therapy. More genomic studies will be required to elucidate the contri- 
butions of clonal heterogeneity to chemoresistance.

\section{Significance of Subpopulations}

Cooperative subpopulations with divergent expression of NE markers have been identified in multiple studies, but their relationship to intertumoral heterogeneity remains unclear. Global differences between SCLC tumors may be the consequence of varying ratios of recurrent cell types, which may be influenced by clonal mutations such as those in NOTCH1-4. Identification of subpopulations responsible for drug resistance will be particularly important. The next steps to investigate intratumoral heterogeneity, such as multilineage tracing experiments in GEMMs (Yang et al. 2018) and single-cell catalogues of multiple cases to define recurrent subpopulations (Su et al. 2019; Stewart et al. 2020) are now being reported. It will also be important to determine whether an underlying feature of SCLC is responsible for its intrinsic intratumoral heterogeneity. Loss of RB1 may be partially responsible, as RB can regulate lineage commitment (Ku et al. 2017; Mu et al. 2017) and inhibit pluripotency networks (Kareta et al. 2015; Dyson 2016; Dick et al. 2018); and in lung adenocarcinoma, deletion of $R B 1$ has been shown to promote lineage plasticity (Walter et al. 2019).

\section{CELL OF ORIGIN AND TRANSDIFFERENTIATION}

In contrast to NSCLC, current early detection strategies are ineffective for SCLC even among high-risk populations. Most SCLC cases detected by computed tomography (CT) screening are already late stage, and many progress so rapidly that they manifest within the screening interval (National Lung Screening Trial Research Team et al. 2011; Aberle et al. 2013; Pinsky et al. 2013; Silva et al. 2016; Thomas et al. 2018). This explosive growth and early dissemination precludes detection of precancerous lesions that could reveal the cell of origin, which remains unknown. Loss of RB1 and TP53 are necessary for tumorigenesis, but without knowing the cellular context their specific roles in driving oncogenesis remain incompletely defined.

\section{Pulmonary Neuroendocrine Cells}

In the RP GEMM, SCLC arises most efficiently from pulmonary NE cells (PNECs), but may arise in other contexts as well (Fig. 2; Sutherland et al. 2011). Tissue-specific promoters were used in an attempt to restrict deletion of $R b 1$ and Trp53 in three cell types: (1) club cells, which line the trachea, bronchi, and small airways; (2) PNECs, which are dispersed throughout intrapulmonary airways and cluster at airway junctions; and (3) type 2 alveolar cells (AT2). SCLC arose with greatest efficiency from PNECs, but could also arise more slowly from AT2 cells and very rarely from club cells. The true specificity of these promoters remains unclear, as a complementary study using different constructs revealed a similar high efficiency of mSCLC tumorigenesis from PNECs but not from AT2 cells (Park et al. 2011).

In a powerful complementary approach, human embryonic stem cells (hESCs) were induced to differentiate into lung precursors (LPs), and combinations of putative SCLC drivers were tested (Chen et al. 2019). NOTCH inhibition could induce LPs to differentiate into PNECs, and in these cells knockdown of $R B 1$ induced nonmalignant proliferation. Combined inactivation of NOTCH, RB1, and TP53 drove formation of xenografts that grossly resembled SCLC, establishing a minimal set of oncogenic events. This mechanism of tumorigenesis was strongly reinforced by the recent finding that following mouse lung epithelial injury, a subset of cells in neuroendocrine bodies (NEBs) activate Notch signaling, proliferate, migrate to the site of injury, and differentiate to restore the surrounding normal epithelium (Ouadah et al. 2019). This subset of NE stem cells $\left(\mathrm{NE}^{\text {stem }}\right)$ can be prevented from reentering quiescence with ablation of $R b 1$ and $\operatorname{Trp} 53$, and remain both proliferative and migratory. Taken together, these mouse and hESC studies suggest that PNECs are the principal cell of origin for SCLC. 


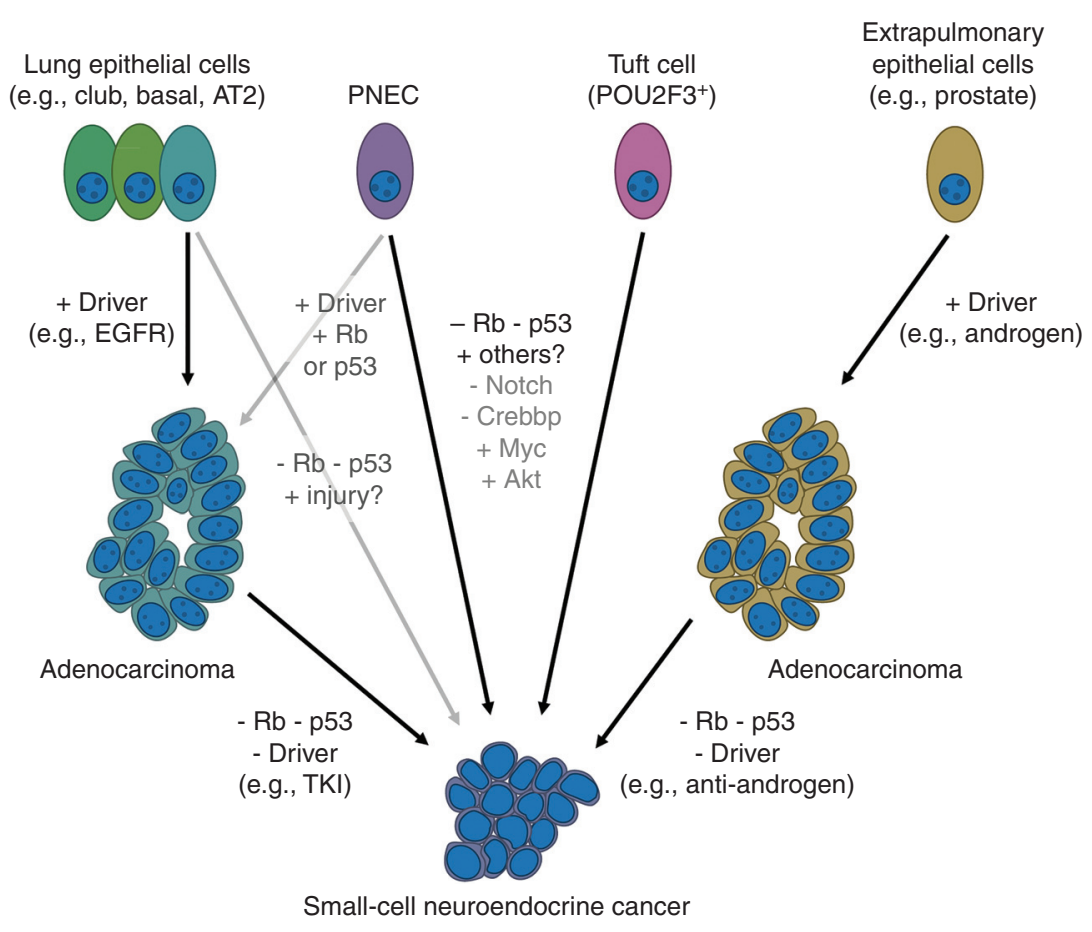

Figure 2. Cell of origin versus destination phenotype. Multiple cells of origin have been implicated as contributing to small-cell lung cancer (SCLC). As described in detail in the text, current models point to pulmonary neuroendocrine cells (PNECs) as a primary cell of origin; recent data also implicates a second cell, the tuft cell, as a putative progenitor of the POU2F3-driven subtype of SCLC. Lung adenocarcinoma can transdifferentiate to an SCLC phenotype through lineage plasticity under targeted therapy selection, and what appears to be an analogous pathway to small-cell neuroendocrine cancers has been defined for extrapulmonary adenocarcinomas, most notably prostate cancer.

\section{Lineage Plasticity and Transdifferentiation}

Normal healthy lung does not undergo rapid cell turnover. However, following epithelial injury, robust tissue regeneration occurs, and during this process there is a high degree of lineage plasticity (Tata and Rajagopal 2017). Examples from diverse lung injury models include restoration of the multipotent basal cell compartment from club cells (Tata et al. 2013), repopulation of AT2 progenitors from AT1 cells (Jain et al. 2015), and regeneration of club and ciliated cells from PNECs in a Notch-dependent process (Yao et al. 2018). Lineage plasticity within nonmalignant pulmonary epithelium raises the possibility that for SCLC, NE differentiation could occur during or even after tumorigenesis. This possibility is reinforced by the phenome- non of transdifferentiation of adenocarcinomas to small-cell neuroendocrine cancers (SCNCs).

EGFR tyrosine kinase inhibitors (TKIs) are highly effective therapies for lung adenocarcinomas with activating EGFR mutations, but they are not curative (Mok et al. 2009, 2017; Soria et al. 2018). In 3\%-10\% of cases, TKI-resistant tumors assume the histologic characteristics of SCLC (Sequist et al. 2011; Yu et al. 2013a; Piotrowska et al. 2018; Bordi et al. 2019), and, in these cases, RB1 and TP53 are inactivated and mutant EGFR expression is low-to-absent (Niederst et al. 2015; Lee et al. 2017). Clinical outcomes following transdifferentiation are similar to de novo SCLC, with initial chemosensitivity followed by relapse and progressive chemoresistance (Marcoux et al. 2019). EGFR-mutant SCLC mirrors the molecular, phenotypic, and 
clinical characteristics of smoking-related $E G F R^{W T}$ SCLC, including lack of dependence on the EGFR oncogene.

However, it is not clear when transdifferentiation occurs. Comparison of serial biopsies before and after transdifferentiation suggests that the SCLC subclone diverges before TKI therapy, and loss of RB1 and TP53 are early events (Lee et al. 2017). Consistent with early divergence, the majority of SCLCs that emerge following third-generation TKIs for $E G F R^{T 790 M}$ resistance lack the T790M gatekeeper mutation (Marcoux et al. 2019). Furthermore, SCLC with activating EGFR mutations can also arise de novo in nonsmokers (Varghese et al. 2014; Le et al. 2015; Sun et al. 2015). A similar phenomenon has been observed in prostate cancer that becomes castrate-resistant through NE differentiation (CRPC-NE) and loses androgen receptor expression (Beltran et al. 2011, 2016; Tzelepi et al. 2012; Tan et al. 2014), RB1 and TP53 (Ku et al. 2017; Mu et al. 2017). As with lung adenocarcinoma, reconstructed clonal evolution trees from serial biopsies suggests early divergence of the CRPC-NE precursor (Beltran et al. 2016).

\section{Origin versus Destination}

SCNCs arise frequently in lung, prostate, and bladder, and have been reported in nearly every organ (Frazier et al. 2007). The histopathology of these cancers appears very similar despite diverse and anatomically distinct cells of origin. Recent pancancer bioinformatic analyses have extended this observation to integrate genomic, transcriptional, and epigenetic data (Smith et al. 2018; Balanis et al. 2019). Principal component analysis revealed that while transcriptomes from normal lung, prostate, and bladder form widely separated clusters, adenocarcinomas are more similar and SCNCs overlap completely (Balanis et al. 2019). SCNCs are distinguished by the expression of adult stem cell markers, and at the core of this expression signature are targets of DNA methyltransferases (DNMTs) that regulate cell fate and apoptosis, including ASCL1 (Smith et al. 2018). Convergence of gene expression suggests that a common set of oncogenic events may lead to SCNCs. This was tested di- rectly in primary cell culture transformation assays, in which inactivation of RB1 and TP53 combined with activation/overexpression of $A K T 1, M Y C$, and BCL2 could induce either prostate basal cells or bronchial epithelial cells to form SCNC xenografts (Park et al. 2018). Although derived from different organs, the transcriptomes and chromatin landscapes of these SCNCs were nearly indistinguishable. Together, these studies raise the question of whether SCNCs are best understood as the consequence of oncogenic transformation of a single cell of origin, or as a destination cancer phenotype that can be reached from multiple tissues.

\section{CHEMORESISTANCE AND DNA DAMAGE REPAIR}

DNA-damaging chemotherapy and ionizing radiation are the mainstays of both local and systemic control of SCLC. Untreated SCLC is highly sensitive to first-line platinum plus etoposide, with clinical response rates that nearly double those of NSCLC (Sandler et al. 2006; Scagliotti et al. 2008; Rossi et al. 2012; Socinski et al. 2012; Patel et al. 2013; Horn et al. 2018; Owonikoko et al. 2019). However, relapse and resistance inevitably arise, and response rates to second-line agents are far lower because of the emergence of cross-resistance (Owonikoko et al. 2012). To discover new therapeutic targets, protein expression was compared between SCLC and NSCLC cell lines by reverse phase protein array (RPPA), and high expression of PARP1 and EZH2 were identified as features of SCLC (Byers et al. 2012). These expression features have contributed to two strategies to exploit the vulnerability of SCLC to DNA damage: (1) combination of DNA-damaging agents with inhibitors of repair, such as PARP inhibitors; and (2) direct reversal of chemoresistance through EZH2 inhibition (Fig. 3).

\section{PARP Inhibitors}

PARP1/2 activity mediates both single- and double-stranded DNA break repair (Ray Chaudhuri and Nussenzweig 2017), and PARP inhibitors are effective in tumors with impaired 


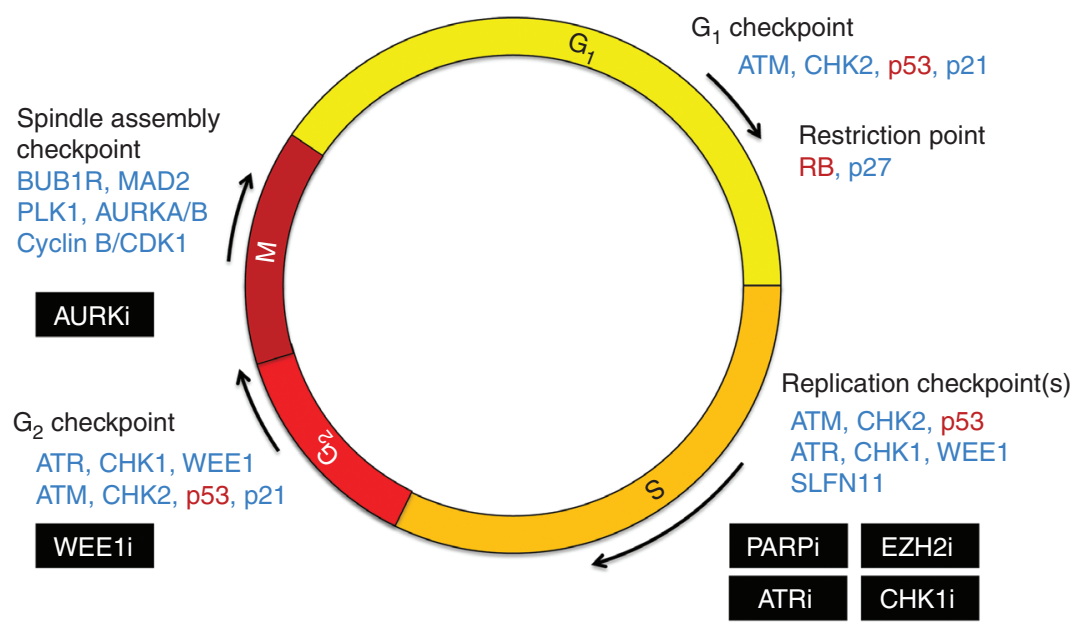

Figure 3. DNA damage checkpoints and vulnerabilities in small-cell lung cancer (SCLC). The universal inactivation of the tumor-suppressor genes TP53 and RB1 in SCLC disrupts several key cell-cycle checkpoints, affecting cell-cycle entry from $G_{1}$ to $S$, response to DNA damage in $S$ phase, and commitment to mitotic entry in $G_{2}$. The loss of these checkpoints may increase dependence on remaining checkpoint pathways, creating a synthetic vulnerability in SCLC to inhibitors of DNA damage repair pathways. Critical factors lost in SCLC are indicated in red, additional notable factors controlling cell-cycle progression are indicated in blue, and targeted therapies being explored in SCLC are boxed in black.

homologous recombination (Turner et al. 2004; Bryant et al. 2005; Farmer et al. 2005; Fong et al. 2009; Audeh et al. 2010; Tutt et al. 2010; Li and Yu 2013). SCLC cell lines are highly sensitive to PARP inhibitors despite little evidence of defective DNA repair (George et al. 2015; Lok et al. 2017). In addition to catalytic inhibition, PARP inhibitors can block the release of PARP complexes from single-stranded breaks, resulting in "trapped" complexes that interfere with both DNA replication and transcription (Murai et al. 2012, 2014; Hopkins et al. 2015). PARP inhibitors vary in trapping efficiency, and the most efficient, such as talazoparib, synergize strongly with both DNA-damaging agents and ionizing radiation in SCLC (Murai et al. 2014; Lok et al. 2017; Laird et al. 2018). Clinical trial data reflects this combinatorial efficacy. Whereas single-agent PARP inhibitors were ineffective in SCLC patients, addition of the PARP inhibitor veliparib to first-line cisplatin/EP resulted in a modest but significant increase in progressionfree survival (PFS) (de Bono et al. 2017; Woll et al. 2017; Owonikoko et al. 2019). In relapsed SCLC, combination of veliparib with temozolo- mide (TMZ) showed a marked increase in response rate (39\% veliparib/TMZ vs. $14 \%$ placebo/TMZ) (Pietanza et al. 2018), and a similarly high response rate was observed with olaparib/ TMZ (42\%) in a single-arm study (Farago et al. 2019). PARP inhibitor combinations are active in unstratified SCLC patients, but predictive biomarkers will likely be required to maximize clinical efficacy.

\section{SLFN11 and Chemosensitivity}

An unbiased cell line screen for biomarker candidates for topoisomerase I (TOP1) revealed that Schlafen 11 (SLFN11) expression strongly correlated with sensitivity to a broad spectrum of DNA-damaging agents and inhibitors of repair (Zoppoli et al. 2012). This correlation has since been confirmed in both pancancer and SCLC-specific cell line screens (Barretina et al. 2012; Garnett et al. 2012; Sousa et al. 2015; Polley et al. 2016; Reinhold et al. 2017). Suppression of SLFN11 confers resistance to DNA damage (Nogales et al. 2016; Tang et al. 2018), and in the setting of replication stress SLFN11 appears to 
irreversibly block stalled replication forks, resulting in cytotoxic double-stranded breaks (Murai et al. 2018). SLFN11 is expressed in approximately half of all cancer cell lines, including many SCLCs (Barretina et al. 2012; Murai et al. 2016; Lok et al. 2017). This bimodal expression pattern has facilitated development of an immunohistochemistry (IHC) assay, and among SCLC PDX models sensitivity to talazoparib correlated with positive IHC staining (Lok et al. 2017). Retrospective analysis of the randomized phase II trial of veliparib plus TMZ revealed a substantial increase in PFS for SLFN11 $\mathrm{IHC}^{+}$patients receiving the combination (mPFS 5.7 vs. 3.6 months), but not TMZ plus placebo (Pietanza et al. 2018). If SLFN11 is prospectively validated for patient selection, veliparib/TMZ may represent the first biomarkertargeted therapy for SCLC.

\section{EZH2 and Chemoresistance}

SLFN11 expression correlates with sensitivity to a broad spectrum of DNA-damaging agents, including EP, and its expression is frequently silenced via promoter methylation, histone methylation, and histone deacetylation (Barretina et al. 2012; Zoppoli et al. 2012; Nogales et al. 2016; Stewart et al. 2017; Reinhold et al. 2017; Tang et al. 2018). Expression of the histone methyltransferase EZH2 is a distinguishing feature of SCLC (Byers et al. 2012; Poirier et al. 2015). To discover mediators of acquired chemoresistance, 10 PDX models derived from chemosensitive SCLC patients were treated in vivo with EP until full resistance emerged (Gardner et al. 2017). Decreased SLFN11 expression was among the most significant changes, and EZH2 inhibition both restored SLFN11 expression and prolonged efficacy of EP. Among the PDX models with unchanged SLFN11 levels, recurrent upregulation of TWIST was observed, consistent with a mesenchymal expression profile reported in chemoresistant SCLC cell lines (Stewart et al. 2017). In PDX models derived from both chemo-naive and postrelapse patients, high levels of MYC-regulated transcripts and low basal expression of inflammatory-response genes correlated with intrinsic resistance to EP as well as other DNA-damaging agents (Drapkin et al. 2018; Farago et al. 2019), and single-cell analysis of PDX models revealed increasing intratumoral heterogeneity with resistance (Stewart et al. 2020).

\section{Relapsed SCLC}

Following diagnostic biopsy, SCLC is rarely sampled, and as a result most information about the biology of human tumors has been gleaned from untreated patients (Peifer et al. 2012; Rudin et al. 2012b; George et al. 2015). This is beginning to change. In a single-institution study, postrelapse tumor samples were obtained from 30 patients, including 12 patients with paired pretreatment samples (Wagner et al. 2018). Recurrent WNT pathway alterations were observed, and APC inactivation conferred resistance to EP in SCLC cell lines. A CTC-based classifier that distinguishes platinum-sensitive from resistant patients remains unchanged in paired postrelapse samples, suggesting that de novo and acquired resistance mechanisms may be distinct (Carter et al. 2017). CTC and ctDNA analyses may be the fastest way to assemble a well-powered cohort for a comprehensive survey of relapsed SCLC.

The rapid progress in targeting DNA damage sensitivity in SCLC has inspired numerous ongoing clinical trials, but important questions remain. Although SCLC has a high mutational burden, and loss of RB can contribute to genomic instability (Manning et al. 2010, 2014; Cook et al. 2015; Vélez-Cruz et al. 2016), it is not clear that SCLC tumors are genomically unstable. Low clonal heterogeneity and infrequent acquisition of new mutations with passaging of PDX models or in serially collected primary tumor samples argue for a surprising degree of genomic stability (George et al. 2015; Ben-David et al. 2017; Drapkin et al. 2018; Wagner et al. 2018). In light of these observations, an explanation for the extreme sensitivity of untreated SCLC to DNA damage remains to be elucidated, as DNA damage repair appears to be generally intact. Direct comparison of pre- and posttreatment models from patients with significant clinical responses may provide insight into 
the relevant mechanisms. Finally, it is unclear whether resistance to DNA damage arises from a preexisting subpopulation of cells or is acquired stochastically during therapy. Discovery of resistant subpopulations may be facilitated by classification of SCLC tumors at the single-cell level.

\section{IMMUNOSUPPRESSIVE PHENOTYPE AND IMMUNOTHERAPY}

$\mathrm{T}$-cell activation requires both antigen presentation and a costimulatory signal (Bretscher 1999). Activation by self-antigens is averted by coinhibitory signals through receptors such as cytotoxic T-lymphocyte-associated protein 4 (CTLA-4) (Tivol et al. 1995; Waterhouse et al. 1995) and programmed death protein 1 (PD-1) (Nishimura et al. 1999; Freeman et al. 2000; Latchman et al. 2001). Tumors may co-opt the machinery of self-tolerance by expressing PD-1 ligand (PD-L1) (Dong et al. 2002; Iwai et al. 2002), and reactivation of costimulatory signaling with immune checkpoint inhibitors (ICIs) such as humanized antibodies against CTLA-4 (e.g., ipilimumab, tremelimumab), PD-1 (pembrolizumab, nivolumab), and PD-L1 (atezolizumab, durvalumab) (Abril-Rodriguez and Ribas 2017) has proven to be highly effective at enhancing antitumor immunity (Allison et al. 1995; Leach et al. 1996).

ICIs have revolutionized the management of NSCLC. For metastatic NSCLC without a targetable oncogenic driver, PD-(L)1-directed ICIs are superior to chemotherapy alone (Langer et al. 2016; Reck et al. 2016a, 2019; Gandhi et al. 2018; Paz-Ares et al. 2018; Socinski et al. 2018; Mok et al. 2019) and have become standard-of-care first-line therapy. In this setting, PD-L1 IHC is an approved biomarker (Reck et al. 2016a; Gandhi et al. 2018; Mok et al. 2019), and tumor mutational burden (TMB) may further refine patient selection (Rizvi et al. 2015; Carbone et al. 2017; Hellmann et al. 2018a). With additional indications following relapse in ICI-naive patients (Borghaei et al. 2015; Brahmer et al. 2015; Fehrenbacher et al. 2016; Herbst et al. 2016; Rittmeyer et al. 2017), and as consolidation therapy following chemo- radiation for unresectable stage III disease (Antonia et al. 2018), ICI antibodies have rapidly become part of the backbone of systemic therapy for NSCLC.

Many of the ICI susceptibility features in NSCLC are even more pronounced in SCLC. SCLC occurs almost exclusively in patients with heavy tobacco exposure (Pesch et al. 2012), carries a higher median mutational burden (9.9 mutations/Mb vs. 6.3-9 NSCLC) (Chalmers et al. 2017), and lacks the recurrent driver alterations in EGFR or ALK that correlate with poor response to ICIs (Gainor et al. 2016; Lisberg et al. 2018; Hastings et al. 2019). Furthermore, SCLC tumors can spontaneously provoke strong immune responses. In a prospective study of 264 patients, $9.4 \%$ developed paraneoplastic neurologic syndromes (PNSs) associated with expression of neuronal antigens on tumor cells (Gozzard et al. 2015). Lambert-Eaton myasthenic syndrome (LEMS) is the most common PNS, developing in 3\%-4\% of SCLC patients (Elrington et al. 1991; Payne et al. 2010; Gozzard et al. 2015), and in both retrospective and prospective studies LEMS correlates with a significant increase in overall survival (Chalk et al. 1990; Maddison et al. 1999, 2017; Payne et al. 2010). For some patients with anti-Hu-associated primary sensory neuropathy (PSN) diagnosis of occult SCLC was only made at autopsy (Dalmau et al. 1992), suggesting disease control despite the devastating neurologic consequences. The burden of smoking-associated mutations and frequency of spontaneous antitumor immune reactions provide a rationale for the potential activity of ICIs.

This potential was partially realized in 2018, as the addition of atezolizumab to first-line carboplatin/plus etoposide (EC) significantly prolonged PFS and overall survival for patients with extensive-stage disease (mOS 12.3 months vs. 10.3 months, mPFS 5.2 months vs. 4.2 months) (Horn et al. 2018). This trial represented a landmark achievement as the first significant improvement in systemic therapy for untreated SCLC since the advent of platinum-containing combinations in the 1980s (Chute et al. 1999; Pujol et al. 2000). However, the gain in survival was modest relative to those achieved in NSCLC, 
and response rate was unaffected. Similar results were subsequently observed with addition of durvalumab to first-line therapy, with a modest increase in response rate and overall survival, but no difference in median PFS (overall response rate [ORR] $79 \%$ vs. $70 \%$, mOS 13 months vs. 10.3 months, mPFS 5.1 months vs. 5.4 months) (Paz-Ares et al. 2019). Addition of ipilimumab to first-line chemotherapy did not significantly prolong PFS (Reck et al. 2016b). In patients with recurrent metastatic SCLC, nivolumab has demonstrated clinical activity both alone and in combination with ipilimumab (Antonia et al. 2016; Ready et al. 2019), as has pembrolizumab (Ott et al. 2017; Chung et al. 2019), and both have been granted accelerated Food and Drug Administration (FDA) approvals for this indication. However, most SCLC patients receive two lines of therapy or fewer (Steffens et al. 2019), and second-line nivolumab demonstrated a lower response rate and PFS relative to chemotherapy (Reck et al. 2018). Thus, despite some features that suggest SCLC should be more vulnerable to ICIs than NSCLC, the clinical data to date has been less compelling.

The determinants of ICI activity in SCLC may differ from those of NSCLC and other solid tumors. Expression of PD-L1 is much lower in SCLC (Borghaei et al. 2015; Brahmer et al. 2015; Schultheis et al. 2015; Antonia et al. 2016; Yu et al. 2017; Socinski et al. 2018), and cancer cell expression of PD-L1 has not correlated with ICI efficacy. Although TMB as measured in ctDNA did not predict benefit of addition of atezolizumab to first-line therapy (Horn et al. 2018), tissue-based TMB may be a promising biomarker for ICI efficacy following relapse (Hellmann et al. 2018b; Ricciuti et al. 2019). However, even if ICI efficacy for SCLC patients correlates with TMB, the increase in sensitivity per nonsynonymous mutation is significantly lower than for most other tumors (Yarchoan et al. 2017). The disparity between ICI efficacy and TMB, as well as the lack of correlation with PD-L1 staining, suggest that coinhibitory signaling may be less important for evasion of immune surveillance in SCLC than in NSCLC.
Antigen presentation in SCLC may be defective due to suppressed inflammation and expression of MHC class I pathway components. Surface expression and messenger RNA (mRNA) levels of HLA-A,B,C and $\beta 2$ microglobulin are orders of magnitude lower in SCLC cell lines compared with NSCLC (Doyle et al. 1985; Yazawa et al. 1999), and these cell lines are less immunogenic when injected into immunocompetent mice (Doyle et al. 1987). SCLC tumor microenvironments are notable for scant immune infiltrates (Kellish et al. 2019), and both the presence of effector $\mathrm{T}$ cells and expression of immune-related genes such as B2M correlate with earlier stage and better prognosis (Koyama et al. 2008; Wang et al. 2013; Bonanno et al. 2018; Muppa et al. 2019). Exogenous interferon can restore MHC class I expression (Funa et al. 1986; Fisk et al. 1994; Traversari et al. 1997), and although interferon treatment did not improve survival in SCLC (Jett et al. 1994; Kelly et al. 1995; van Zandwijk et al. 1997), these trials were conducted before the advent of ICIs and could have been confounded by interferon-stimulated expression of PD-L1 (Tseng et al. 2001; Dong et al. 2002; Kim et al. 2005; Garcia-Diaz et al. 2017). A recent screen for mediators of MHC-I transcriptional silencing identified multiple components of the polycomb repressor complex 2 (PRC2), and pharmacologic inhibitors of either EED or EZH2 restored MHC-I expression and antigen presentation (Burr et al. 2019). SCLC is characterized by high expression of EZH2 (Byers et al. 2012), and in the EZH2 inhibition overcomes resistance to T-cellmediated killing in the RP GEMM. ICI combination with PRC2 inhibition constitutes a promising experimental approach that merits testing in clinical trials.

Alternative strategies for enhancing immunoresponsiveness of SCLC are being explored. Induction of RAS signaling in SCLC cell line NCI-H69 results in production of type I interferon and expression of both MHC class I and PD-L1 (Cañadas et al. 2014, 2018). This inflammatory phenotype was traced to derepression of a subclass of endogenous retroviruses (ERVs) embedded in the $3^{\prime}$-UTRs of interferon-stimulated genes. ERV transcription activates both the 
RLR/MAVS and cGAS/STING pathways, which in turn stimulate further interferon production and ERV transcription in a feedforward loop. Inhibitors of DNA repair, such as PARP and CHK1 inhibitors, can directly activate the cGAS-STING pathway through release of damaged genomic DNA into the cytosol, and combination of PARP inhibition and PD-L1 blockade resulted in dramatic regressions in mSCLC tumors (Sen et al. 2019). A similar phenomenon was observed for a novel selective inhibitor of CKD7, which induced a DNA replication stress response and subsequent stimulation of dormant immune surveillance (Zhang et al. 2020). Although a trial of combination durvalumab and olaparib did not meet the preset bar for efficacy, responses were observed in all tumors with significant CD8-positive T-cell infiltrates (Thomas et al. 2019).

Evasion of immune surveillance appears to be different for SCLC from NSCLC, and will require a distinct therapeutic approach, but rapid progress is being made in elucidating these mechanisms. Development of patient-derived models that can faithfully recapitulate clinical response and resistance to immunotherapy would accelerate progress, but this is a challenging technical hurdle. Alternatively, the development of GEMMs with a similar TMB to the human disease may better simulate response to immune checkpoint blockade.

\section{CONCLUSION}

SCLC research has accelerated over the past decade. Advances in genomics and development of diverse mouse- and patient-derived models have facilitated insights into the cell(s) of origin, intratumoral heterogeneity, gene dependencies, immune evasion, and chemoresistance mechanisms of this disease. SCLC is now being subdivided into functional and molecular categories, a prerequisite for development of biomarker-directed therapy. Pancancer studies suggest greater biological similarity with smallcell NE cancers arising from other organs than with NSCLC, and the therapeutic advances made in SCLC will likely benefit the broader population of solid tumor patients whose can- cers become resistant to therapy through smallcell transformation.

\section{REFERENCES}

Aberle DR, DeMello S, Berg CD, Black WC, Brewer B, Church TR, Clingan KL, Duan F, Fagerstrom RM, Gareen IF, et al. 2013. Results of the two incidence screenings in the National Lung Screening Trial. N Engl J Med 369: 920-931. doi:10.1056/NEJMoa1208962

Abril-Rodriguez G, Ribas A. 2017. SnapShot: immune checkpoint inhibitors. Cancer Cell 31: 848-8e1. doi:10 .1016/j.ccell.2017.05.010

Allison JP, Hurwitz AA, Leach DR. 1995. Manipulation of costimulatory signals to enhance antitumor T-cell responses. Curr Opin Immunol 7: 682-686. doi:10.1016/ 0952-7915(95)80077-8

American Cancer Society. 2020. Cancer facts \& figures. The American Cancer Society, Atlanta, GA. https://www cancer.org/research/cancer-facts-statistics/all-cancer-factsfigures/cancer-facts-figures-2020.html.

Antonia SJ, López-Martin JA, Bendell J, Ott PA, Taylor M, Eder JP, Jäger D, Pietanza MC, Le DT, de Braud F, et al. 2016. Nivolumab alone and nivolumab plus ipilimumab in recurrent small-cell lung cancer (CheckMate 032): a multicentre, open-label, phase $1 / 2$ trial. Lancet Oncol 17: 883-895. doi:10.1016/S1470-2045(16) 30098-5

Antonia SJ, Villegas A, Daniel D, Vicente D, Murakami S, Hui R, Kurata T, Chiappori A, Lee KH, de Wit M, et al. 2018. Overall survival with durvalumab after chemoradiotherapy in stage III NSCLC. N Engl J Med 379: 2342 2350. doi:10.1056/NEJMoa1809697

Aparicio S, Hidalgo M, Kung AL. 2015. Examining the utility of patient-derived xenograft mouse models. Nat Rev Cancer 15: 311-316. doi:10.1038/nrc3944

Audeh MW, Carmichael J, Penson RT, Friedlander M, Powell B, Bell-McGuinn KM, Scott C, Weitzel JN, Oaknin A, Loman N, et al. 2010. Oral poly(ADP-ribose) polymerase inhibitor olaparib in patients with BRCA1 or BRCA2 mutations and recurrent ovarian cancer: a proof-of-concept trial. Lancet 376: 245-251. doi:10.1016/S0140-6736 (10)60893-8

Augert A, Eastwood E, Ibrahim AH, Wu N, Grunblatt E, Basom R, Liggitt D, Eaton KD, Martins R, Poirier JT, et al. 2019. Targeting NOTCH activation in small cell lung cancer through LSD1 inhibition. Sci Signal 12: eaau2922. doi:10.1126/scisignal.aau2922

Augustyn A, Borromeo M, Wang T, Fujimoto J, Shao C Dospoy PD, Lee V, Tan C, Sullivan JP, Larsen JE, et al. 2014. ASCL1 is a lineage oncogene providing therapeutic targets for high-grade neuroendocrine lung cancers. Proc Natl Acad Sci 111: 14788-14793. doi:10.1073/pnas.141 0419111

Baillie-Johnson H, Twentyman PR, Fox NE, Walls GA, Workman P, Watson JV, Johnson N, Reeve JG, Bleehen NM. 1985. Establishment and characterisation of cell lines from patients with lung cancer (predominantly small cell carcinoma). Br J Cancer 52: 495-504. doi:10 $.1038 /$ bjc. 1985.220 
Balanis NG, Sheu KM, Esedebe FN, Patel SJ, Smith BA, Park JW, Alhani S, Gomperts BN, Huang J, Witte ON, et al. 2019. Pan-cancer convergence to a small-cell neuroendocrine phenotype that shares susceptibilities with hematological malignancies. Cancer Cell 36: 17-34.e7. doi:10 .1016/j.ccell.2019.06.005

Barretina J, Caponigro G, Stransky N, Venkatesan K, Margolin AA, Kim S, Wilson CJ, Lehár J, Kryukov GV, Sonkin D, et al. 2012. The Cancer Cell Line Encyclopedia enables predictive modelling of anticancer drug sensitivity. $\mathrm{Na}$ ture 483: 603-607. doi:10.1038/nature11003

Beltran H, Rickman DS, Park K, Chae SS, Sboner A, MacDonald TY, Wang Y, Sheikh KL, Terry S, Tagawa ST, et al. 2011. Molecular characterization of neuroendocrine prostate cancer and identification of new drug targets. Cancer Discov 1: 487-495. doi:10.1158/2159-8290.CD11-0130

Beltran H, Prandi D, Mosquera JM, Benelli M, Puca L, Cyrta J, Marotz C, Giannopoulou E, Chakravarthi BV, Varambally S, et al. 2016. Divergent clonal evolution of castration-resistant neuroendocrine prostate cancer. Nat Med 22: 298-305. doi:10.1038/nm.4045

Ben-David U, Ha G, Tseng YY, Greenwald NF, Oh C, Shih J, McFarland JM, Wong B, Boehm JS, Beroukhim R, et al. 2017. Patient-derived xenografts undergo mouse-specific tumor evolution. Nat Genet 49: 1567-1575. doi:10.1038/ ng.3967

Bevilacqua S, Gallo M, Franco R, Rossi A, De Luca A, Rocco G, Botti G, Gridelli C, Normanno N. 2009. A "live" biopsy in a small-cell lung cancer patient by detection of circulating tumor cells. Lung Cancer 65: 123-121. doi:10 .1016/j.lungcan.2009.01.019

Bonanno L, Pavan A, Dieci MV, Di Liso E, Schiavon M, Comacchio G, Attilli I, Pasello G, Calabrese F, Rea F, et al. 2018. The role of immune microenvironment in smallcell lung cancer: distribution of PD-L1 expression and prognostic role of FOXP3-positive tumour infiltrating lymphocytes. Eur J Cancer 101: 191-200. doi:10.1016/j .ejca.2018.06.023

Bordi P, Del Re M, Minari R, Rofi E, Buti S, Restante G, Squadrilli A, Crucitta S, Casartelli C, Gnetti L, et al. 2019. From the beginning to resistance: study of plasma monitoring and resistance mechanisms in a cohort of patients treated with osimertinib for advanced T790Mpositive NSCLC. Lung Cancer 131: 78-85. doi:10.1016/j .lungcan.2019.03.017

Borges M, Linnoila RI, van de Velde HJ, Chen H, Nelkin BD, Mabry M, Baylin SB, Ball DW. 1997. An achaete-scute homologue essential for neuroendocrine differentiation in the lung. Nature 386: 852-855. doi:10.1038/386852a0

Borghaei H, Paz-Ares L, Horn L, Spigel DR, Steins M, Ready NE, Chow LQ, Vokes EE, Felip E, Holgado E, et al. 2015. Nivolumab versus docetaxel in advanced nonsquamous non-small-cell lung cancer. N Engl J Med 373: 1627-1639. doi:10.1056/NEJMoa1507643

Borromeo MD, Savage TK, Kollipara RK, He M, Augustyn A, Osborne JK, Girard L, Minna JD, Gazdar AF, Cobb $\mathrm{MH}$, et al. 2016. ASCL1 and NEUROD1 reveal heterogeneity in pulmonary neuroendocrine tumors and regulate distinct genetic programs. Cell Rep 16: 1259-1272. doi:10 .1016/j.celrep.2016.06.081
Brahmer J, Reckamp KL, Baas P, Crinò L, Eberhardt WE, Poddubskaya E, Antonia S, Pluzanski A, Vokes EE, Holgado E, et al. 2015. Nivolumab versus docetaxel in advanced squamous-cell non-small-cell lung cancer. $N$ Engl J Med 373: 123-135. doi:10.1056/NEJMoa1504627

Bretscher PA. 1999. A two-step, two-signal model for the primary activation of precursor helper T cells. Proc Natl Acad Sci 96: 185-190. doi:10.1073/pnas.96.1.185

Bryant HE, Schultz N, Thomas HD, Parker KM, Flower D, Lopez E, Kyle S, Meuth M, Curtin NJ, Helleday T. 2005. Specific killing of BRCA2-deficient tumours with inhibitors of poly(ADP-ribose) polymerase. Nature 434: $913-$ 917. doi:10.1038/nature 03443

Burr ML, Sparbier CE, Chan KL, Chan YC, Kersbergen A, Lam EYN, Azidis-Yates E, Vassiliadis D, Bell CC, Gilan O, et al. 2019. An evolutionarily conserved function of polycomb silences the MHC class I antigen presentation pathway and enables immune evasion in cancer. Cancer Cell 36: 385-401.e8. doi:10.1016/j.ccell.2019.08.008

Byers LA, Rudin CM. 2015. Small cell lung cancer: where do we go from here? Cancer 121: 664-672. doi:10.1002/cncr .29098

Byers LA, Wang J, Nilsson MB, Fujimoto J, Saintigny P, Yordy J, Giri U, Peyton M, Fan YH, Diao L, et al. 2012. Proteomic profiling identifies dysregulated pathways in small cell lung cancer and novel therapeutic targets including PARP1. Cancer Discov 2: 798-811. doi:10.1158/ 2159-8290.CD-12-0112

Calbo J, Meuwissen R, van Montfort E, van Tellingen O, Berns A. 2005. Genotype-phenotype relationships in a mouse model for human small-cell lung cancer. Cold Spring Harb Symp Quant Biol 70: 225-232. doi:10.1101/ sqb.2005.70.026

Calbo J, van Montfort E, Proost N, van Drunen E, Beverloo HB, Meuwissen R, Berns A. 2011. A functional role for tumor cell heterogeneity in a mouse model of small cell lung cancer. Cancer Cell 19: 244-256. doi:10.1016/j.ccr .2010.12.021

Cañadas I, Rojo F, Taus Á, Arpí O, Arumí-Uría M, Pijuan L, Menéndez S, Zazo S, Dómine M, Salido M, et al. 2014. Targeting epithelial-to-mesenchymal transition with Met inhibitors reverts chemoresistance in small cell lung cancer. Clin Cancer Res 20: 938-950. doi:10.1158/1078-0432 .CCR-13-1330

Cañadas I, Thummalapalli R, Kim JW, Kitajima S, Jenkins RW, Christensen CL, Campisi M, Kuang Y, Zhang Y, Gjini E, et al. 2018. Tumor innate immunity primed by specific interferon-stimulated endogenous retroviruses. Nat Med 24: 1143-1150. doi:10.1038/s41591-018-0116-5

Cao L, Faha B, Dembski M, Tsai LH, Harlow E, Dyson N. 1992. Independent binding of the retinoblastoma protein and p107 to the transcription factor E2F. Nature 355: 176-179. doi:10.1038/355176a0

Carbone DP, Reck M, Paz-Ares L, Creelan B, Horn L, Steins M, Felip E, van den Heuvel MM, Ciuleanu TE, Badin F, et al. 2017. First-line nivolumab in stage IV or recurrent non-small-cell lung cancer. $N$ Engl J Med 376: $2415-$ 2426. doi:10.1056/NEJMoa1613493

Carney DN, Gazdar AF, Minna JD. 1980. Positive correlation between histological tumor involvement and generation of tumor cell colonies in agarose in specimens taken di- 
rectly from patients with small-cell carcinoma of the lung. Cancer Res 40: 1820-1823.

Carney DN, Gazdar AF, Bepler G, Guccion JG, Marangos PJ, Moody TW, Zweig MH, Minna JD. 1985. Establishment and identification of small cell lung cancer cell lines having classic and variant features. Cancer Res 45: 29132923.

Carter L, Rothwell DG, Mesquita B, Smowton C, Leong HS, Fernandez-Gutierrez F, Li Y, Burt DJ, Antonello J, Morrow CJ, et al. 2017. Molecular analysis of circulating tumor cells identifies distinct copy-number profiles in patients with chemosensitive and chemorefractory smallcell lung cancer. Nat Med 23: 114-119. doi:10.1038/nm .4239

Chalishazar MD, Wait SJ, Huang F, Ireland AS, Mukhopadhyay A, Lee Y, Schuman SS, Guthrie MR, Berrett KC, Vahrenkamp JM, et al. 2019. MYC-driven small-cell lung cancer is metabolically distinct and vulnerable to arginine depletion. Clin Cancer Res 25: 5107-5121. doi:10.1158/1078-0432.CCR-18-4140

Chalk CH, Murray NM, Newsom-Davis J, O’Neill JH, Spiro SG. 1990. Response of the Lambert-Eaton myasthenic syndrome to treatment of associated small-cell lung carcinoma. Neurology 40: 1552-1556. doi:10.1212/WNL.40 .10 .1552

Chalmers ZR, Connelly CF, Fabrizio D, Gay L, Ali SM, Ennis R, Schrock A, Campbell B, Shlien A, Chmielecki J, et al. 2017. Analysis of 100,000 human cancer genomes reveals the landscape of tumor mutational burden. Genome Med 9: 34. doi:10.1186/s13073-017-0424-2

Chen H, Thiagalingam A, Chopra H, Borges MW, Feder JN, Nelkin BD, Baylin SB, Ball DW. 1997. Conservation of the Drosophila lateral inhibition pathway in human lung cancer: a hairy-related protein (HES-1) directly represses achaete-scute homolog-1 expression. Proc Natl Acad Sci 94: 5355-5360. doi:10.1073/pnas.94.10.5355

Chen HJ, Poran A, Unni AM, Huang SX, Elemento O, Snoeck HW, Varmus H. 2019. Generation of pulmonary neuroendocrine cells and SCLC-like tumors from human embryonic stem cells. J Exp Med 216: 674-687. doi:10 $.1084 /$ jem. 20181155

Chung HC, Ros W, Delord JP, Perets R, Italiano A, ShapiraFrommer R, Manzuk L, Piha-Paul SA, Xu L, Zeigenfuss S, et al. 2019. Efficacy and safety of pembrolizumab in previously treated advanced cervical cancer: results from the phase II KEYNOTE-158 study. J Clin Oncol 37: 14701478. doi:10.1200/JCO.18.01265

Chute JP, Chen T, Feigal E, Simon R, Johnson BE. 1999. Twenty years of phase III trials for patients with extensive-stage small-cell lung cancer: perceptible progress. $J$ Clin Oncol 17: 1794-1801. doi:10.1200/JCO.1999.17.6 .1794

Cobrinik D, Whyte P, Peeper DS, Jacks T, Weinberg RA. 1993. Cell cycle-specific association of E2F with the p130 E1A-binding protein. Genes Dev 7: 2392-2404. doi:10.1101/gad.7.12a.2392

Cook R, Zoumpoulidou G, Luczynski MT, Rieger S, Moquet J, Spanswick VJ, Hartley JA, Rothkamm K, Huang PH, Mittnacht S. 2015. Direct involvement of retinoblastoma family proteins in DNA repair by non-homologous endjoining. Cell Rep 10: 2006-2018. doi:10.1016/j.celrep .2015 .02 .059
Small-Cell Lung Cancer Translational Research

Cui M, Augert A, Rongione M, Conkrite K, Parazzoli S, Nikitin AY, Ingolia N, MacPherson D. 2014. PTEN is a potent suppressor of small cell lung cancer. Mol Cancer Res 12: 654-659. doi:10.1158/1541-7786.MCR-13-0554

Dalmau J, Graus F, Rosenblum MK, Posner JB. 1992. Anti-Hu-associated paraneoplastic encephalomyelitis/ sensory neuronopathy. A clinical study of 71 patients. Medicine (Baltimore) 71: 59-72. doi:10.1097/00005792199203000-00001

Daniel VC, Marchionni L, Hierman JS, Rhodes JT, Devereux WL, Rudin CM, Yung R, Parmigiani G, Dorsch M, Peacock CD, et al. 2009. A primary xenograft model of smallcell lung cancer reveals irreversible changes in gene expression imposed by culture in vitro. Cancer Res 69: 3364-3373. doi:10.1158/0008-5472.CAN-08-4210

de Bono J, Ramanathan RK, Mina L, Chugh R, Glaspy J, Rafii S, Kaye S, Sachdev J, Heymach J, Smith DC, et al. 2017. Phase I, dose-escalation, two-part trial of the PARP inhibitor talazoparib in patients with advanced germline BRCA1/2 mutations and selected sporadic cancers. Cancer Discov 7: 620-629. doi:10.1158/2159-8290.CD-161250

Denny SK, Yang D, Chuang CH, Brady JJ, Lim JS, Grüner BM, Chiou SH, Schep AN, Baral J, Hamard C, et al. 2016. Nfib promotes metastasis through a widespread increase in chromatin accessibility. Cell 166: 328-342. doi:10 .1016/j.cell.2016.05.052

Dick FA, Goodrich DW, Sage J, Dyson NJ. 2018. Non-canonical functions of the RB protein in cancer. Nat Rev Cancer 18: 442-451. doi:10.1038/s41568-018-0008-5

Dong H, Strome SE, Salomao DR, Tamura H, Hirano F, Flies DB, Roche PC, Lu J, Zhu G, Tamada K, et al. 2002. Tumor-associated B7-H1 promotes T-cell apoptosis: a potential mechanism of immune evasion. Nat Med 8: 793800. doi:10.1038/nm730

Dooley AL, Winslow MM, Chiang DY, Banerji S, Stransky N, Dayton TL, Snyder EL, Senna S, Whittaker CA, Bronson RT, et al. 2011. Nuclear factor I/B is an oncogene in small cell lung cancer. Genes Dev 25: 1470-1475. doi:10.1101/ gad.2046711

Doyle A, Martin WJ, Funa K, Gazdar A, Carney D, Martin SE, Linnoila I, Cuttitta F, Mulshine J, Bunn P 1985. Markedly decreased expression of class I histocompatibility antigens, protein, and mRNA in human small-cell lung cancer. J Exp Med 161: 1135-1151. doi:10.1084/jem.161.5 .1135

Doyle LA, Cuttitta F, Mulshine JL, Bunn PA, Minna JD. 1987. Markedly different antibody responses to immunized small cell and non-small cell lung cancer cells. Cancer Res 47: 5009-5013.

Doyle LA, Borges M, Hussain A, Elias A, Tomiyasu T. 1990. An adherent subline of a unique small-cell lung cancer cell line downregulates antigens of the neural cell adhesion molecule. J Clin Invest 86: 1848-1854. doi:10.1172/ JCI114915

Drapkin BJ, George J, Christensen CL, Mino-Kenudson M, Dries R, Sundaresan T, Phat S, Myers DT, Zhong J, Igo P, et al. 2018. Genomic and functional fidelity of small cell lung cancer patient-derived xenografts. Cancer Discov 8: 600-615. doi:10.1158/2159-8290.CD-17-0935 
Dyson NJ. 2016. RB1: a prototype tumor suppressor and an enigma. Genes Dev 30: 1492-1502. doi:10.1101/gad .282145 .116

Dyson N, Guida P, Münger K, Harlow E. 1992. Homologous sequences in adenovirus E1A and human papillomavirus E7 proteins mediate interaction with the same set of cellular proteins. J Virol 66: 6893-6902. doi:10.1128/JVI.66 .12.6893-6902.1992

Elrington GM, Murray NM, Spiro SG, Newsom-Davis J. 1991. Neurological paraneoplastic syndromes in patients with small cell lung cancer. A prospective survey of 150 patients. J Neurol Neurosurg Psychiatry 54: 764-767. doi:10.1136/jnnp.54.9.764

Farago AF, Yeap BY, Stanzione M, Hung YP, Heist RS, Marcoux JP, Zhong J, Rangachari D, Barbie DA, Phat S, et al 2019. Combination olaparib and temozolomide in relapsed small cell lung cancer. Cancer Discov 9: 1372 1387. doi:10.1158/2159-8290.CD-19-0582

Fargion S, Carney D, Mulshine J, Rosen S, Bunn P, Jewett P, Cuttitta F, Gazdar A, Minna J. 1986. Heterogeneity of cell surface antigen expression of human small cell lung cancer detected by monoclonal antibodies. Cancer Res 46: 2633-2638.

Farmer H, McCabe N, Lord CJ, Tutt AN, Johnson DA, Richardson TB, Santarosa M, Dillon KJ, Hickson I Knights C, et al. 2005. Targeting the DNA repair defect in BRCA mutant cells as a therapeutic strategy. Nature 434: 917-921. doi:10.1038/nature03445

Fehrenbacher L, Spira A, Ballinger M, Kowanetz M, Vansteenkiste J, Mazieres J, Park K, Smith D, Artal-Cortes A, Lewanski C, et al. 2016. Atezolizumab versus docetaxel for patients with previously treated non-small-cell lung cancer (POPLAR): a multicentre, open-label, phase 2 randomised controlled trial. Lancet 387: 1837-1846. doi:10.1016/S0140-6736(16)00587-0

Fisk B, Ioannides CG, Aggarwal S, Wharton JT, O'Brian CA Restifo N, Glisson BS. 1994. Enhanced expression of HLA-A,B,C and inducibility of TAP-1, TAP-2, and HLA-A,B,C by interferon- $\gamma$ in a multidrug-resistant small cell lung cancer line. Lymphokine Cytokine Res 13: 125131.

Flores ER, Tsai KY, Crowley D, Sengupta S, Yang A, McKeon F, Jacks T. 2002. p63 and p73 are required for p53-dependent apoptosis in response to DNA damage. Nature 416: 560-564. doi:10.1038/416560a

Fong PC, Boss DS, Yap TA, Tutt A, Wu P, Mergui-Roelvink M, Mortimer P, Swaisland H, Lau A, O'Connor MJ, et al. 2009. Inhibition of poly(ADP-ribose) polymerase in tumors from $B R C A$ mutation carriers. N Engl J Med 361: 123-134. doi:10.1056/NEJMoa0900212

Frazier SR, Kaplan PA, Loy TS. 2007. The pathology of extrapulmonary small cell carcinoma. Semin Oncol 34: 3038. doi:10.1053/j.seminoncol.2006.11.017

Freeman GJ, Long AJ, Iwai Y, Bourque K, Chernova T, Nishimura H, Fitz LJ, Malenkovich N, Okazaki T, Byrne $\mathrm{MC}$, et al. 2000. Engagement of the PD-1 immunoinhibitory receptor by a novel B7 family member leads to negative regulation of lymphocyte activation. J Exp Med 192: 1027-1034. doi:10.1084/jem.192.7.1027

Funa K, Gazdar AF, Mattson K, Niiranen A, Koivuniemi A, Öberg K, Wilander E, Doyle A, Linnoila RI. 1986. Interferon-mediated in vivo induction of $\beta 2$-microglobulin on small-cell lung cancers and mid-gut carcinoids. Clin Immunol Immunopathol 41: 159-164. doi:10.1016/00901229(86)90060-7

Gainor JF, Shaw AT, Sequist LV, Fu X, Azzoli CG, Piotrowska Z, Huynh TG, Zhao L, Fulton L, Schultz KR, et al. 2016. EGFR mutations and ALK rearrangements are associated with low response rates to PD-1 pathway blockade in non-small cell lung cancer: a retrospective analysis. Clin Cancer Res 22: 4585-4593. doi:10.1158/1078-0432.CCR15-3101

Gandhi L, Rodríguez-Abreu D, Gadgeel S, Esteban E, Felip E, De Angelis F, Domine M, Clingan P, Hochmair MJ, Powell SF, et al. 2018. Pembrolizumab plus chemotherapy in metastatic non-small-cell lung cancer. $N$ Engl J Med 378: 2078-2092. doi:10.1056/NEJMoa1801005

Garcia-Diaz A, Shin DS, Moreno BH, Saco J, Escuin-Ordinas H, Rodriguez GA, Zaretsky JM, Sun L, Hugo W, Wang X, et al. 2017. Interferon receptor signaling pathways regulating PD-L1 and PD-L2 expression. Cell Rep 19: 11891201. doi:10.1016/j.celrep.2017.04.031

Gardner EE, Lok BH, Schneeberger VE, Desmeules P, Miles LA, Arnold PK, Ni A, Khodos I, de Stanchina E, Nguyen T, et al. 2017. Chemosensitive relapse in small cell lung cancer proceeds through an EZH2-SLFN11 axis. Cancer Cell 31: 286-299. doi:10.1016/j.ccell.2017.01.006

Garnett MJ, Edelman EJ, Heidorn SJ, Greenman CD, Dastur A, Lau KW, Greninger P, Thompson IR, Luo X, Soares J, et al. 2012. Systematic identification of genomic markers of drug sensitivity in cancer cells. Nature 483: 570-575. doi:10.1038/nature11005

Gazdar AF, Minna JD. 1996. NCI series of cell lines: an historical perspective. J Cell Biochem (Suppl.) 24: 1-11.

Gazdar AF, Carney DN, Nau MM, Minna JD. 1985. Characterization of variant subclasses of cell lines derived from small cell lung cancer having distinctive biochemical, morphological, and growth properties. Cancer Res 45: 2924-2930.

Gazdar AF, Savage TK, Johnson JE, Berns A, Sage J, Linnoila RI, MacPherson D, McFadden DG, Farago A, Jacks T, et al. 2015. The comparative pathology of genetically engineered mouse models for neuroendocrine carcinomas of the lung. J Thorac Oncol 10: 553-564. doi:10.1097/JTO .0000000000000459

George J, Lim JS, Jang SJ, Cun Y, Ozretić L, Kong G, Leenders F, Lu X, Fernández-Cuesta L, Bosco G, et al. 2015. Comprehensive genomic profiles of small cell lung cancer. Nature 524: 47-53. doi:10.1038/nature14664

Gozzard P, Woodhall M, Chapman C, Nibber A, Waters P, Vincent A, Lang B, Maddison P. 2015. Paraneoplastic neurologic disorders in small cell lung carcinoma: a prospective study. Neurology 85: 235-239. doi:10.1212/WNL 0000000000001721

Guillemot F, Lo LC, Johnson JE, Auerbach A, Anderson DJ, Joyner AL. 1993. Mammalian achaete-scute homolog 1 is required for the early development of olfactory and autonomic neurons. Cell 75: 463-476. doi:10.1016/0092-8674 (93)90381-Y

Haber DA, Velculescu VE. 2014. Blood-based analyses of cancer: circulating tumor cells and circulating tumor DNA. Cancer Discov 4: 650-661. doi:10.1158/21598290.CD-13-1014 
Hann CL, Daniel VC, Sugar EA, Dobromilskaya I, Murphy SC, Cope L, Lin X, Hierman JS, Wilburn DL, Watkins DN, et al. 2008. Therapeutic efficacy of ABT-737, a selective inhibitor of BCL-2, in small cell lung cancer. Cancer Res 68: 2321-2328. doi:10.1158/0008-5472.CAN-07-5031

Harbour JW, Lai SL, Whang-Peng J, Gazdar AF, Minna JD, Kaye FJ. 1988. Abnormalities in structure and expression of the human retinoblastoma gene in SCLC. Science 241: 353-357. doi:10.1126/science.2838909

Hastings K, Yu H, Wei W, Sanchez-Vega F, DeVeaux M, Choi J, Rizvi H, Lisberg A, Truini A, Lydon CA, et al. 2019. EGFR mutation subtypes and response to immune checkpoint blockade treatment in non-small cell lung cancer. Ann Oncol 30: 1311-1320. doi:10.1093/annoncl mdz141

Hellmann MD, Ciuleanu TE, Pluzanski A, Lee JS, Otterson GA, Audigier-Valette C, Minenza E, Linardou H, Burgers S, Salman P, et al. 2018a. Nivolumab plus ipilimumab in lung cancer with a high tumor mutational burden. NEngl J Med 378: 2093-2104. doi:10.1056/NEJMoa1801946

Hellmann MD, Callahan MK, Awad MM, Calvo E, Ascierto PA, Atmaca A, Rizvi NA, Hirsch FR, Selvaggi G, Szustakowsi JD, et al. 2018b. Tumor mutational burden and efficacy of nivolumab monotherapy and in combination with ipilimumab in small-cell lung cancer. Cancer Cell 33: 853-861.e4. doi:10.1016/j.ccell.2018.04.001

Hendrix MJ, Seftor EA, Hess AR, Seftor RE. 2003. Vasculogenic mimicry and tumour-cell plasticity: lessons from melanoma. Nat Rev Cancer 3: 411-421. doi:10.1038/ nrc1092

Hensel CH, Hsieh CL, Gazdar AF, Johnson BE, Sakaguchi AY, Naylor SL, Lee WH, Lee EY. 1990. Altered structure and expression of the human retinoblastoma susceptibility gene in small cell lung cancer. Cancer Res 50: 30673072.

Hensel CH, Xiang RH, Sakaguchi AY, Naylor SL. 1991. Use of the single strand conformation polymorphism technique and PCR to detect p53 gene mutations in small cell lung cancer. Oncogene 6: 1067-1071.

Herbst RS, Baas P, Kim DW, Felip E, Pérez-Gracia JL, Han JY, Molina J, Kim JH, Arvis CD, Ahn MJ, et al. 2016. Pembrolizumab versus docetaxel for previously treated, PD-L1-positive, advanced non-small-cell lung cancer (KEYNOTE-010): a randomised controlled trial. Lancet 387: 1540-1550. doi:10.1016/S0140-6736(15)01281-7

Hidalgo M, Amant F, Biankin AV, Budinská E, Byrne AT, Caldas C, Clarke RB, de Jong S, Jonkers J, Mælandsmo GM, et al. 2014. Patient-derived xenograft models: an emerging platform for translational cancer research. Cancer Discov 4: 998-1013. doi:10.1158/2159-8290.CD-140001

Hodgkinson CL, Morrow CJ, Li Y, Metcalf RL, Rothwell DG, Trapani F, Polanski R, Burt DJ, Simpson KL, Morris K, et al. 2014. Tumorigenicity and genetic profiling of circulating tumor cells in small-cell lung cancer. Nat Med 20: 897-903. doi:10.1038/nm.3600

Hook KE, Garza SJ, Lira ME, Ching KA, Lee NV, Cao J, Yuan J, Ye J, Ozeck M, Shi ST, et al. 2012. An integrated genomic approach to identify predictive biomarkers of response to the aurora kinase inhibitor PF-03814735. Mol Cancer Ther 11: 710-719. doi:10.1158/1535-7163.MCT11-0184
Hopkins TA, Shi Y, Rodriguez LE, Solomon LR, Donawho CK, DiGiammarino EL, Panchal SC, Wilsbacher JL, Gao W, Olson AM, et al. 2015. Mechanistic dissection of PARP1 trapping and the impact on in vivo tolerability and efficacy of PARP inhibitors. Mol Cancer Res 13: 1465-1477. doi:10.1158/1541-7786.MCR-15-0191-T

Horn L, Mansfield AS, Szczęsna A, Havel L, Krzakowski M, Hochmair MJ, Huemer F, Losonczy G, Johnson ML, Nishio M, et al. 2018. First-line atezolizumab plus chemotherapy in extensive-stage small-cell lung cancer. $N$ Engl J Med 379: 2220-2229. doi:10.1056/NEJMoa 1809064

Hou JM, Greystoke A, Lancashire L, Cummings J, Ward T, Board R, Amir E, Hughes S, Krebs M, Hughes A, et al. 2009. Evaluation of circulating tumor cells and serological cell death biomarkers in small cell lung cancer patients undergoing chemotherapy. Am J Pathol 175: 808-816. doi:10.2353/ajpath.2009.090078

Hou JM, Krebs MG, Lancashire L, Sloane R, Backen A, Swain RK, Priest LJ, Greystoke A, Zhou C, Morris K, et al. 2012. Clinical significance and molecular characteristics of circulating tumor cells and circulating tumor microemboli in patients with small-cell lung cancer. J Clin Oncol 30: 525-532.

Huang YH, Klingbeil O, He XY, Wu XS, Arun G, Lu B, Somerville TDD, Milazzo JP, Wilkinson JE, Demerdash OE, et al. 2018. POU2F3 is a master regulator of a tuft celllike variant of small cell lung cancer. Genes Dev 32: 915928. doi:10.1101/gad.314815.118

Hulton CH, Costa EA, Shah NS, Quintanal-Villalonga A, Heller G, de Stanchina E, Rudin CM, Poirier JT. 2020. Direct genome editing of patient-derived xenografts using CRISPR-Cas9 enables rapid in vivo functional genomics. Nature Cancer 1: 359-369. doi:10.1038/s43018-0200040-8

Ikegaki N, Katsumata M, Minna J, Tsujimoto Y. 1994. Expression of bcl-2 in small cell lung carcinoma cells. Cancer Res 54: 6-8.

Imielinski M, Berger AH, Hammerman PS, Hernandez B, Pugh TJ, Hodis E, Cho J, Suh J, Capelletti M, Sivachenko A, et al. 2012. Mapping the hallmarks of lung adenocarcinoma with massively parallel sequencing. Cell 150: 1107-1120. doi:10.1016/j.cell.2012.08.029

Ito T, Udaka N, Yazawa T, Okudela K, Hayashi H, Sudo T, Guillemot F, Kageyama R, Kitamura H. 2000. Basic helixloop-helix transcription factors regulate the neuroendocrine differentiation of fetal mouse pulmonary epithelium. Development 127: 3913-3921.

Iwai Y, Ishida M, Tanaka Y, Okazaki T, Honjo T, Minato N. 2002. Involvement of PD-L1 on tumor cells in the escape from host immune system and tumor immunotherapy by PD-L1 blockade. Proc Natl Acad Sci 99: 12293-12297. doi:10.1073/pnas.192461099

Iwakawa R, Kohno T, Totoki Y, Shibata T, Tsuchihara K, Mimaki S, Tsuta K, Narita Y, Nishikawa R, Noguchi M, et al. 2015. Expression and clinical significance of genes frequently mutated in small cell lung cancers defined by whole exome/RNA sequencing. Carcinogenesis 36: 616621. doi:10.1093/carcin/bgv026

Jahchan NS, Lim JS, Bola B, Morris K, Seitz G, Tran KQ, Xu L, Trapani F, Morrow CJ, Cristea S, et al. 2016. Identification and targeting of long-term tumor-propagating 
B.J. Drapkin and C.M. Rudin

cells in small cell lung cancer. Cell Rep 16: 644-656. doi:10 .1016/j.celrep.2016.06.021

Jain R, Barkauskas CE, Takeda N, Bowie EJ, Aghajanian H, Wang Q, Padmanabhan A, Manderfield LJ, Gupta M, Li D, et al. 2015. Plasticity of $\mathrm{Hopx}^{+}$type I alveolar cells to regenerate type II cells in the lung. Nat Commun 6: 6727. doi:10.1038/ncomms7727

Jett JR, Maksymiuk AW, Su JQ, Mailliard JA, Krook JE, Tschetter LK, Kardinal CG, Twito DI, Levitt R, Gerstner JB. 1994. Phase III trial of recombinant interferon $\gamma$ in complete responders with small-cell lung cancer. J Clin Oncol 12: 2321-2326. doi:10.1200/JCO.1994.12.11.2321

Jia D, Augert A, Kim DW, Eastwood E, Wu N, Ibrahim AH, Kim KB, Dunn CT, Pillai SPS, Gazdar AF, et al. 2018. Crebbp loss drives small cell lung cancer and increases sensitivity to HDAC inhibition. Cancer Discov 8: 14221437. doi:10.1158/2159-8290.CD-18-0385

Jiang T, Collins BJ, Jin N, Watkins DN, Brock MV, Matsui W, Nelkin BD, Ball DW. 2009. Achaete-scute complex homologue 1 regulates tumor-initiating capacity in human small cell lung cancer. Cancer Res 69: 845-854. doi:10 .1158/0008-5472.CAN-08-2762

Johnson BE, Russell E, Simmons AM, Phelps R, Steinberg SM, Ihde DC, Gazdar AF. 1996. MYC family DNA amplification in 126 tumor cell lines from patients with small cell lung cancer. J Cell Biochem Suppl 24: 210-217. doi:10 $.1002 /$ jcb. 240630516

Jost CA, Marin MC, Kaelin WG Jr. 1997. p73 is a simian [correction of human] p53-related protein that can induce apoptosis. Nature 389: 191-194. doi:10.1038/38298

Kalemkerian GP. 2014. Advances in pharmacotherapy of small cell lung cancer. Expert Opin Pharmacother 15: 2385-2396. doi:10.1517/14656566.2014.957180

Karabacak NM, Spuhler PS, Fachin F, Lim EJ, Pai V, Ozkumur E, Martel JM, Kojic N, Smith K, Chen PI, et al. 2014. Microfluidic, marker-free isolation of circulating tumor cells from blood samples. Nat Protoc 9: 694-710. doi:10 $.1038 /$ nprot.2014.044

Kareta MS, Gorges LL, Hafeez S, Benayoun BA, Marro S, Zmoos AF, Cecchini MJ, Spacek D, Batista LF, O’Brien M, et al. 2015. Inhibition of pluripotency networks by the $\mathrm{Rb}$ tumor suppressor restricts reprogramming and tumorigenesis. Cell Stem Cell 16: 39-50.

Kaur G, Reinhart RA, Monks A, Evans D, Morris J, Polley E, Teicher BA. 2016. Bromodomain and hedgehog pathway targets in small cell lung cancer. Cancer Lett 371: 225239. doi:10.1016/j.canlet.2015.12.001

Kellish P, Shabashvili D, Rahman MM, Nawab A, Guijarro MV, Zhang M, Cao C, Moussatche N, Boyle T, Antonia S, et al. 2019. Oncolytic virotherapy for small-cell lung cancer induces immune infiltration and prolongs survival. $J$ Clin Invest 129: 2279-2292. doi:10.1172/JCI121323

Kelly K, Crowley JJ, Bunn PA Jr, Hazuka MB, Beasley K, Upchurch C, Weiss GR, Hicks WJ, Gandara DR, Rivkin S. 1995. Role of recombinant interferon alfa-2a maintenance in patients with limited-stage small-cell lung cancer responding to concurrent chemoradiation: a Southwest Oncology Group study. J Clin Oncol 13: 2924-2930. doi:10.1200/JCO.1995.13.12.2924

Kim SK, Su LK, Oh Y, Kemp BL, Hong WK, Mao L. 1998. Alterations of PTEN/MMAC1, a candidate tumor suppressor gene, and its homologue, PTH2, in small cell lung cancer cell lines. Oncogene 16: 89-93. doi:10.1038/ sj.onc. 1201512

Kim J, Myers AC, Chen L, Pardoll DM, Truong-Tran QA, Lane AP, McDyer JF, Fortuno L, Schleimer RP. 2005. Constitutive and inducible expression of b7 family of ligands by human airway epithelial cells. Am J Respir Cell Mol Biol 33: 280-289. doi:10.1165/rcmb.2004-0129OC

Kim DW, Wu N, Kim YC, Cheng PF, Basom R, Kim D, Dunn CT, Lee AY, Kim K, Lee CS, et al. 2016. Genetic requirement for $\mathrm{Mycl}$ and efficacy of RNA Pol I inhibition in mouse models of small cell lung cancer. Genes Dev 30: 1289-1299. doi:10.1101/gad.279307.116

Koyama K, Kagamu H, Miura S, Hiura T, Miyabayashi T, Itoh R, Kuriyama H, Tanaka H, Tanaka J, Yoshizawa H, et al. 2008. Reciprocal $\mathrm{CD} 4^{+}$T-cell balance of effector CD62 $\mathrm{L}^{\text {low }} \mathrm{CD}^{+}$and $\mathrm{CD} 62 \mathrm{~L}^{\text {high }} \mathrm{CD} 25^{+} \mathrm{CD} 4^{+}$regulatory $\mathrm{T}$ cells in small cell lung cancer reflects disease stage. Clin Cancer Res 14: 6770-6779. doi:10.1158/1078-0432.CCR08-1156

Ku SY, Rosario S, Wang Y, Mu P, Seshadri M, Goodrich ZW, Goodrich MM, Labbé DP, Gomez EC, Wang J, et al. 2017. $R b 1$ and $\operatorname{Tr} p 53$ cooperate to suppress prostate cancer lineage plasticity, metastasis, and antiandrogen resistance. Science 355: 78-83. doi:10.1126/science.aah4199

Kwon MC, Proost N, Song JY, Sutherland KD, Zevenhoven J, Berns A. 2015. Paracrine signaling between tumor subclones of mouse SCLC: a critical role of ETS transcription factor Pea3 in facilitating metastasis. Genes Dev 29: 1587 1592. doi:10.1101/gad.262998.115

Laird JH, Lok BH, Ma J, Bell A, de Stanchina E, Poirier JT, Rudin CM. 2018. Talazoparib is a potent radiosensitizer in small cell lung cancer cell lines and xenografts. Clin Cancer Res 24: 5143-5152.

Lallo A, Frese KK, Morrow CJ, Sloane R, Gulati S, Schenk MW, Trapani F, Simms N, Galvin M, Brown S, et al. 2018. The combination of the PARP inhibitor olaparib and the WEE1 inhibitor AZD1775 as a new therapeutic option for small cell lung cancer. Clin Cancer Res 24: 5153-5164.

Lallo A, Gulati S, Schenk MW, Khandelwal G, Berglund UW, Pateras IS, Chester CPE, Pham TM, Kalderen C, Frese KK, et al. 2019. Ex vivo culture of cells derived from circulating tumour cell xenograft to support small cell lung cancer research and experimental therapeutics. $\mathrm{Br}$ J Pharmacol 176: 436-450.

Langer CJ, Gadgeel SM, Borghaei H, Papadimitrakopoulou VA, Patnaik A, Powell SF, Gentzler RD, Martins RG, Stevenson JP, Jalal SI, et al. 2016. Carboplatin and pemetrexed with or without pembrolizumab for advanced, non-squamous non-small-cell lung cancer: a randomised, phase 2 cohort of the open-label KEYNOTE-021 study. Lancet Oncol 17: 1497-1508. doi:10.1016/S14702045(16)30498-3

Latchman Y, Wood CR, Chernova T, Chaudhary D, Borde M, Chernova I, Iwai Y, Long AJ, Brown JA, Nunes R, et al. 2001. PD-L2 is a second ligand for PD-1 and inhibits T cell activation. Nat Immunol 2: 261-268. doi:10.1038/ 85330

Lawrence MS, Stojanov P, Mermel CH, Robinson JT, Garraway LA, Golub TR, Meyerson M, Gabriel SB, Lander ES, Getz G. 2014. Discovery and saturation analysis of cancer genes across 21 tumour types. Nature 505: 495-501. doi:10.1038/nature12912 
Le X, Desai NV, Majid A, Karp RS, Huberman MS, Rangachari D, Kent MS, Gangadharan SP, Folch E, VanderLaan PA, et al. 2015. De novo pulmonary small cell carcinomas and large cell neuroendocrine carcinomas harboring EGFR mutations: lack of response to EGFR inhibitors. Lung Cancer 88: 70-73. doi:10.1016/j.lungcan.2015.02 .003

Leach DR, Krummel MF, Allison JP. 1996. Enhancement of antitumor immunity by CTLA-4 blockade. Science 271 : 1734-1736. doi:10.1126/science.271.5256.1734

Lee JK, Lee J, Kim S, Kim S, Youk J, Park S, An Y, Keam B, Kim DW, Heo DS, et al. 2017. Clonal history and genetic predictors of transformation into small-cell carcinomas from lung adenocarcinomas. J Clin Oncol 35: 3065-3074. doi:10.1200/JCO.2016.71.9096

Li M, Yu X. 2013. Function of BRCA1 in the DNA damage response is mediated by ADP-ribosylation. Cancer Cell 23: 693-704. doi:10.1016/j.ccr.2013.03.025

Lim JS, Ibaseta A, Fischer MM, Cancilla B, O’Young G, Cristea S, Luca VC, Yang D, Jahchan NS, Hamard C, et al. 2017. Intratumoural heterogeneity generated by Notch signalling promotes small-cell lung cancer. Nature 545: 360-364. doi:10.1038/nature22323

Lisberg A, Cummings A, Goldman JW, Bornazyan K, Reese N, Wang T, Coluzzi P, Ledezma B, Mendenhall M, Hunt J, et al. 2018. A phase II study of pembrolizumab in EGFRmutant, $\mathrm{PD}-\mathrm{L}^{+}$, tyrosine kinase inhibitor naive patients with advanced NSCLC. J Thorac Oncol 13: 1138-1145. doi:10.1016/j.jtho.2018.03.035

Little CD, Nau MM, Carney DN, Gazdar AF, Minna JD. 1983. Amplification and expression of the c-myc oncogene in human lung cancer cell lines. Nature 306: 194196. doi:10.1038/306194a 0

Lok BH, Gardner EE, Schneeberger VE, Ni A, Desmeules P, Rekhtman N, de Stanchina E, Teicher BA, Riaz N, Powell SN, et al. 2017. PARP inhibitor activity correlates with SLFN11 expression and demonstrates synergy with temozolomide in small cell lung cancer. Clin Cancer Res 23: 523-535. doi:10.1158/1078-0432.CCR-16-1040

Maddison P, Newsom-Davis J, Mills KR, Souhami RL. 1999. Favourable prognosis in Lambert-Eaton myasthenic syndrome and small-cell lung carcinoma. Lancet 353: 117118. doi:10.1016/S0140-6736(05)76153-5

Maddison P, Gozzard P, Grainge MJ, Lang B. 2017. Longterm survival in paraneoplastic Lambert-Eaton myasthenic syndrome. Neurology 88: 1334-1339. doi:10 $.1212 /$ WNL.0000000000003794

Maniotis AJ, Folberg R, Hess A, Seftor EA, Gardner LM, Pe'er J, Trent JM, Meltzer PS, Hendrix MJ. 1999. Vascular channel formation by human melanoma cells in vivo and in vitro: vasculogenic mimicry. Am J Pathol 155: 739-752. doi:10.1016/S0002-9440(10)65173-5

Manning AL, Longworth MS, Dyson NJ. 2010. Loss of pRB causes centromere dysfunction and chromosomal instability. Genes Dev 24: 1364-1376. doi:10.1101/gad .1917310

Manning AL, Yazinski SA, Nicolay B, Bryll A, Zou L, Dyson NJ. 2014. Suppression of genome instability in pRB-deficient cells by enhancement of chromosome cohesion. Mol Cell 53: 993-1004. doi:10.1016/j.molcel.2014.01.032

Marcoux N, Gettinger SN, O’Kane G, Arbour KC, Neal JW, Husain H, Evans TL, Brahmer JR, Muzikansky A, Bo- nomi PD, et al. 2019. EGFR-mutant adenocarcinomas that transform to small-cell lung cancer and other neuroendocrine carcinomas: clinical outcomes. J Clin Oncol 37: 278-285. doi:10.1200/JCO.18.01585

McFadden DG, Papagiannakopoulos T, Taylor-Weiner A, Stewart C, Carter SL, Cibulskis K, Bhutkar A, McKenna A, Dooley A, Vernon A, et al. 2014. Genetic and clonal dissection of murine small cell lung carcinoma progression by genome sequencing. Cell 156: 1298-1311. doi:10 .1016/j.cell.2014.02.031

Meredith A, Johnson JE. 2000. Negative autoregulation of Mash1 expression in CNS development. Dev Biol 222: 336-346. doi:10.1006/dbio.2000.9697

Meuwissen R, Linn SC, Linnoila RI, Zevenhoven J, Mooi WJ, Berns A. 2003. Induction of small cell lung cancer by somatic inactivation of both Trp53 and Rbl in a conditional mouse model. Cancer Cell 4: 181-189. doi:10.1016/ S1535-6108(03)00220-4

Mok TS, Wu YL, Thongprasert S, Yang CH, Chu DT, Saijo N, Sunpaweravong P, Han B, Margono B, Ichinose Y, et al 2009. Gefitinib or carboplatin-paclitaxel in pulmonary adenocarcinoma. N Engl J Med 361: 947-957. doi:10 .1056/NEJMoa0810699

Mok TS, Wu YL, Ahn MJ, Garassino MC, Kim HR, Ramalingam SS, Shepherd FA, He Y, Akamatsu H, Theelen WS, et al. 2017. Osimertinib or platinum-pemetrexed in EGFR T790M-positive lung cancer. N Engl J Med 376: 629-640. doi:10.1056/NEJMoa1612674

Mok TSK, Wu YL, Kudaba I, Kowalski DM, Cho BC, Turna HZ, Castro G, Srimuninnimit V, Laktionov KK, Bondarenko I, et al. 2019. Pembrolizumab versus chemotherapy for previously untreated, PD-L1-expressing, locally advanced or metastatic non-small-cell lung cancer (KEYNOTE-042): a randomised, open-label, controlled, phase 3 trial. Lancet 393: 1819-1830. doi:10.1016/S0140-6736 (18)32409-7

Mollaoglu G, Guthrie MR, Böhm S, Brägelmann J, Can I, Ballieu PM, Marx A, George J, Heinen C, Chalishazar MD, et al. 2017. MYC drives progression of small cell lung cancer to a variant neuroendocrine subtype with vulnerability to aurora kinase inhibition. Cancer Cell 31: 270-285. doi:10.1016/j.ccell.2016.12.005

Mu P, Zhang Z, Benelli M, Karthaus WR, Hoover E, Chen CC, Wongvipat J, Ku SY, Gao D, Cao Z, et al. 2017. SOX2 promotes lineage plasticity and antiandrogen resistance in TP53- and RB1-deficient prostate cancer. Science 355: 84-88. doi:10.1126/science.aah4307

Muppa P, Parrilha Terra SBS, Sharma A, Mansfield AS, Aubry MC, Bhinge K, Asiedu MK, de Andrade M, Janaki $\mathrm{N}$, Murphy SJ, et al. 2019. Immune cell infiltration may be a key determinant of long-term survival in small cell lung cancer. J Thorac Oncol 14: 1286-1295. doi:10.1016/j.jtho .2019 .03 .028

Murai J, Huang SY, Das BB, Renaud A, Zhang Y, Doroshow JH, Ji J, Takeda S, Pommier Y. 2012. Trapping of PARP1 and PARP2 by clinical PARP inhibitors. Cancer Res 72: 5588-5599. doi:10.1158/0008-5472.CAN-12-2753

Murai J, Huang SY, Renaud A, Zhang Y, Ji J, Takeda S, Morris J, Teicher B, Doroshow JH, Pommier Y. 2014 Stereospecific PARP trapping by BMN 673 and comparison with olaparib and rucaparib. Mol Cancer Ther 13: 433-443. doi:10.1158/1535-7163.MCT-13-0803 
Murai J, Feng Y, Yu GK, Ru Y, Tang SW, Shen Y, Pommier Y 2016. Resistance to PARP inhibitors by SLFN11 inactivation can be overcome by ATR inhibition. Oncotarget 7: 76534-76550.

Murai J, Tang SW, Leo E, Baechler SA, Redon CE, Zhang H, Al Abo M, Rajapakse VN, Nakamura E, Jenkins LMM, et al. 2018. SLFN11 blocks stressed replication forks independently of ATR. Mol Cell 69: 371-384.e6. doi:10.1016/j .molcel.2018.01.012

Naito T, Tanaka F, Ono A, Yoneda K, Takahashi T, Murakami H, Nakamura Y, Tsuya A, Kenmotsu H, Shukuya T, et al. 2012. Prognostic impact of circulating tumor cells in patients with small cell lung cancer. $J$ Thorac Oncol 7: 512-519. doi:10.1097/JTO.0b013e31823f125d

National Lung Screening Trial Research Team; Aberle DR, Adams AM, Berg CD, Black WC, Clapp JD, Fagerstrom RM, Gareen IF, Gatsonis C, Marcus PM, et al. 2011. Reduced lung-cancer mortality with low-dose computed tomographic screening. $N$ Engl J Med 365: 395-409. doi:10.1056/NEJMoa1102873

Nau MM, Brooks BJ, Battey J, Sausville E, Gazdar AF, Kirsch IR, McBride OW, Bertness V, Hollis GF, Minna JD. 1985. L-myc, a new myc-related gene amplified and expressed in human small cell lung cancer. Nature 318: 69-73. doi:10.1038/318069a0

Nau MM, Brooks BJ Jr, Carney DN, Gazdar AF, Battey JF, Sausville EA, Minna JD. 1986. Human small-cell lung cancers show amplification and expression of the Nmyc gene. Proc Natl Acad Sci 83: 1092-1096. doi:10 $.1073 /$ pnas.83.4.1092

Némati F, Daniel C, Arvelo F, Legrier ME, Froget B, Livartowski A, Assayag F, Bourgeois Y, Poupon MF, Decaudin D. 2010. Clinical relevance of human cancer xenografts as a tool for preclinical assessment: example of in-vivo evaluation of topotecan-based chemotherapy in a panel of human small-cell lung cancer xenografts. Anticancer Drugs 21: 25-32. doi:10.1097/CAD.0b013e3283300a29

Niederst MJ, Sequist LV, Poirier JT, Mermel CH, Lockerman EL, Garcia AR, Katayama R, Costa C, Ross KN, Moran T, et al. 2015. RB loss in resistant EGFR mutant lung adenocarcinomas that transform to small-cell lung cancer. Nat Commun 6: 6377. doi:10.1038/ncomms7377

Nishimura H, Nose M, Hiai H, Minato N, Honjo T. 1999. Development of lupus-like autoimmune diseases by disruption of the PD-1 gene encoding an ITIM motif-carrying immunoreceptor. Immunity 11: 141-151. doi:10 .1016/S1074-7613(00)80089-8

Nogales V, Reinhold WC, Varma S, Martinez-Cardus A, Moutinho C, Moran S, Heyn H, Sebio A, Barnadas A, Pommier Y, et al. 2016. Epigenetic inactivation of the putative DNA/RNA helicase SLFN11 in human cancer confers resistance to platinum drugs. Oncotarget 7: 3084-3097. doi:10.18632/oncotarget.6413

Nong J, Gong Y, Guan Y, Yi X, Yi Y, Chang L, Yang L, Lv J, Guo Z, Jia H, et al. 2018. Circulating tumor DNA analysis depicts subclonal architecture and genomic evolution of small cell lung cancer. Nat Commun 9: 3114. doi:10.1038/ s41467-018-05327-w

Oboshi S, Tsugawa S, Seido T, Shimosato Y, Koide T. 1971. A new floating cell line derived from human pulmonary carcinoma of oat cell type. Gan 62: 505-514.
Olejniczak ET, Van Sant C, Anderson MG, Wang G, Tahir SK, Sauter G, Lesniewski R, Semizarov D. 2007. Integrative genomic analysis of small-cell lung carcinoma reveals correlates of sensitivity to bcl-2 antagonists and uncovers novel chromosomal gains. Mol Cancer Res 5: 331-339. doi:10.1158/1541-7786.MCR-06-0367

Oltersdorf T, Elmore SW, Shoemaker AR, Armstrong RC, Augeri DJ, Belli BA, Bruncko M, Deckwerth TL, Dinges J, Hajduk PJ, et al. 2005. An inhibitor of Bcl-2 family proteins induces regression of solid tumours. Nature 435: 677-681. doi:10.1038/nature03579

Osada H, Tatematsu Y, Yatabe Y, Horio Y, Takahashi T. 2005. ASH1 gene is a specific therapeutic target for lung cancers with neuroendocrine features. Cancer Res $\mathbf{6 5}$ 10680-10685. doi:10.1158/0008-5472.CAN-05-1404

Osborne JK, Larsen JE, Shields MD, Gonzales JX, Shames DS, Sato M, Kulkarni A, Wistuba II, Girard L, Minna JD, et al. 2013. NeuroD1 regulates survival and migration of neuroendocrine lung carcinomas via signaling molecules TrkB and NCAM. Proc Natl Acad Sci 110: 6524-6529. doi:10.1073/pnas.1303932110

Ott PA, Elez E, Hiret S, Kim DW, Morosky A, Saraf S, Piperdi B, Mehnert JM. 2017. Pembrolizumab in patients with extensive-stage small-cell lung cancer: results from the phase Ib KEYNOTE-028 study. J Clin Oncol 35: 3823 3829. doi:10.1200/JCO.2017.72.5069

Ouadah Y, Rojas ER, Riordan DP, Capostagno S, Kuo CS, Krasnow MA. 2019. Rare pulmonary neuroendocrine cells are stem cells regulated by Rb, p53, and Notch. Cell 179: 403-416.e23. doi:10.1016/j.cell.2019.09.010

Owonikoko TK, Behera M, Chen Z, Bhimani C, Curran WJ, Khuri FR, Ramalingam SS. 2012. A systematic analysis of efficacy of second-line chemotherapy in sensitive and refractory small-cell lung cancer. J Thorac Oncol 7: 866872. doi:10.1097/JTO.0b013e31824c7f4b

Owonikoko TK, Dahlberg SE, Sica GL, Wagner LI, Wade JL, Srkalovic G, Lash BW, Leach JW, Leal TB, Aggarwal C, et al. 2019. Randomized phase II trial of cisplatin and etoposide in combination with veliparib or placebo for extensive-stage small-cell lung cancer: ECOG-ACRIN 2511 Study. J Clin Oncol 37: 222-229. doi:10.1200/JCO.18 .00264

Ozkumur E, Shah AM, Ciciliano JC, Emmink BL, Miyamoto DT, Brachtel E, Yu M, Chen PI, Morgan B, Trautwein J, et al. 2013. Inertial focusing for tumor antigen-dependent and -independent sorting of rare circulating tumor cells. Sci Transl Med 5: 179ra47. doi:10.1126/scitranslmed .3005616

Park KS, Liang MC, Raiser DM, Zamponi R, Roach RR, Curtis SJ, Walton Z, Schaffer BE, Roake CM, Zmoos AF, et al. 2011. Characterization of the cell of origin for small cell lung cancer. Cell Cycle 10: 2806-2815. doi:10 $.4161 / \mathrm{cc} .10 .16 .17012$

Park JW, Lee JK, Sheu KM, Wang L, Balanis NG, Nguyen K, Smith BA, Cheng C, Tsai BL, Cheng D, et al. 2018. Reprogramming normal human epithelial tissues to a common, lethal neuroendocrine cancer lineage. Science 362: 91-95. doi:10.1126/science.aat5749

Patel JD, Socinski MA, Garon EB, Reynolds CH, Spigel DR, Olsen MR, Hermann RC, Jotte RM, Beck T, Richards DA, et al. 2013. PointBreak: a randomized phase III study of pemetrexed plus carboplatin and bevacizumab followed 
by maintenance pemetrexed and bevacizumab versus paclitaxel plus carboplatin and bevacizumab followed by maintenance bevacizumab in patients with stage IIIB or IV nonsquamous non-small-cell lung cancer. J Clin Oncol 31: 4349-4357. doi:10.1200/JCO.2012.47.9626

Payne M, Bradbury P, Lang B, Vincent A, Han C, NewsomDavis J, Talbot D. 2010. Prospective study into the incidence of Lambert-Eaton myasthenic syndrome in small cell lung cancer. J Thorac Oncol 5: 34-38. doi:10.1097/ JTO.0b013e3181c3f4f1

Paz-Ares L, Luft A, Vicente D, Tafreshi A, Gümüş M, Mazières J, Hermes B, Çay Șenler F, Csőszi T, Fülöp A, et al. 2018. Pembrolizumab plus chemotherapy for squamous non-small-cell lung cancer. NEngl J Med 379: 2040-2051. doi:10.1056/NEJMoa1810865

Paz-Ares L, Dvorkin M, Chen Y, Reinmuth N, Hotta K, Trukhin D, Statsenko G, Hochmair MJ, Özgüroğlu M, Ji JH, et al. 2019. Durvalumab plus platinum-etoposide versus platinum-etoposide in first-line treatment of extensive-stage small-cell lung cancer (CASPIAN): a randomised, controlled, open-label, phase 3 trial. Lancet 394: 1929-1939. doi:10.1016/S0140-6736(19)32222-6

Peifer M, Fernández-Cuesta L, Sos ML, George J, Seidel D, Kasper LH, Plenker D, Leenders F, Sun R, Zander T, et al. 2012. Integrative genome analyses identify key somatic driver mutations of small-cell lung cancer. Nat Genet 44: 1104-1110. doi:10.1038/ng.2396

Pesch B, Kendzia B, Gustavsson P, Jöckel KH, Johnen G, Pohlabeln H, Olsson A, Ahrens W, Gross IM, Brüske I, et al. 2012. Cigarette smoking and lung cancer-relative risk estimates for the major histological types from a pooled analysis of case-control studies. Int J Cancer 131: 1210-1219. doi:10.1002/ijc.27339

Pettengill OS, Sorenson GD, Wurster-Hill DH, Curphey TJ, Noll WW, Cate CC, Maurer LH. 1980. Isolation and growth characteristics of continuous cell lines from small-cell carcinoma of the lung. Cancer 45: 906-918. $<906$ ::AID-CNCR2820450513>3.0.CO;2-H

Pietanza MC, Waqar SN, Krug LM, Dowlati A, Hann CL, Chiappori A, Owonikoko TK, Woo KM, Cardnell RJ, Fujimoto J, et al. 2018. Randomized, double-blind, phase II study of temozolomide in combination with either veliparib or placebo in patients with relapsed-sensitive or refractory small-cell lung cancer. J Clin Oncol 36: 23862394. doi:10.1200/JCO.2018.77.7672

Pinsky PF, Church TR, Izmirlian G, Kramer BS. 2013. The National Lung Screening Trial: results stratified by demographics, smoking history, and lung cancer histology. Cancer 119: 3976-3983. doi:10.1002/cncr.28326

Piotrowska Z, Isozaki H, Lennerz JK, Gainor JF, Lennes IT, Zhu VW, Marcoux N, Banwait MK, Digumarthy SR, Su W, et al. 2018. Landscape of acquired resistance to osimertinib in EGFR-mutant NSCLC and clinical validation of combined EGFR and RET inhibition with osimertinib and BLU-667 for acquired RET fusion. Cancer Discov 8: 1529-1539. doi:10.1158/2159-8290.CD-18-1022

Pleasance ED, Stephens PJ, O’Meara S, McBride DJ, Meynert A, Jones D, Lin ML, Beare D, Lau KW, Greenman C, et al. 2010. A small-cell lung cancer genome with complex signatures of tobacco exposure. Nature 463: 184-190. doi:10 $.1038 /$ nature 08629
Poirier JT, Dobromilskaya I, Moriarty WF, Peacock CD, Hann CL, Rudin CM. 2013. Selective tropism of Seneca Valley virus for variant subtype small cell lung cancer. $J$ Natl Cancer Inst 105: 1059-1065. doi:10.1093/jnci/djt130

Poirier JT, Gardner EE, Connis N, Moreira AL, de Stanchina E, Hann CL, Rudin CM. 2015. DNA methylation in small cell lung cancer defines distinct disease subtypes and correlates with high expression of EZH2. Oncogene 34: 58695878. doi:10.1038/onc.2015.38

Polley E, Kunkel M, Evans D, Silvers T, Delosh R, Laudeman J, Ogle C, Reinhart R, Selby M, Connelly J, et al. 2016. Small cell lung cancer screen of oncology drugs, investigational agents, and gene and microRNA expression. $J$ Natl Cancer Inst 108: djw122.

Pujol JL, Carestia L, Daurès JP. 2000. Is there a case for cisplatin in the treatment of small-cell lung cancer? A meta-analysis of randomized trials of a cisplatin-containing regimen versus a regimen without this alkylating agent. Br J Cancer 83: 8-15. doi:10.1054/bjoc.2000.1164

Ray Chaudhuri A, Nussenzweig A. 2017. The multifaceted roles of PARP1 in DNA repair and chromatin remodelling. Nat Rev Mol Cell Biol 18: 610-621. doi:10.1038/nrm .2017 .53

Ready N, Farago AF, de Braud F, Atmaca A, Hellmann MD, Schneider JG, Spigel DR, Moreno V, Chau I, Hann CL, et al. 2019. Third-line nivolumab monotherapy in recurrent SCLC: CheckMate 032. J Thorac Oncol 14: 237-244. doi:10.1016/j.jtho.2018.10.003

Reck M, Rodríguez-Abreu D, Robinson AG, Hui R, Csőszi T, Fülöp A, Gottfried M, Peled N, Tafreshi A, Cuffe S, et al. 2016a. Pembrolizumab versus chemotherapy for PD-L1positive non-small-cell lung cancer. $N$ Engl J Med 375: 1823-1833. doi:10.1056/NEJMoa1606774

Reck M, Luft A, Szczesna A, Havel L, Kim SW, Akerley W, Pietanza MC, Wu YL, Zielinski C, Thomas M, et al. 2016b. Phase III randomized trial of ipilimumab plus etoposide and platinum versus placebo plus etoposide and platinum in extensive-stage small-cell lung cancer. J Clin Oncol 34: 3740-3748. doi:10.1200/JCO.2016 .67 .6601

Reck M, Vincente D, Ciuleanu S, Gettinger S, Peters S, Horn L, Audigier-Valette N, Pardo N, Juan-Vidal O, Cheng Y, et al. 2018. Efficacy and safety of nivolumab (nivo) monotherapy versus chemotherapy (chemo) in recurrent small cell lung cancer (SCLC): results from CheckMate 331. Ann Oncol 29: LBA5x39-43.

Reck M, Rodríguez-Abreu D, Robinson AG, Hui R, Csőszi T, Fülöp A, Gottfried M, Peled N, Tafreshi A, Cuffe S, et al. 2019. Updated analysis of KEYNOTE-024: pembrolizumab versus platinum-based chemotherapy for advanced non-small-cell lung cancer with PD-L1 tumor proportion score of 50\% or greater. J Clin Oncol 37: 537-546. doi:10 $.1200 / \mathrm{JCO} .18 .00149$

Reinhold WC, Varma S, Sunshine M, Rajapakse V, Luna A, Kohn KW, Stevenson H, Wang Y, Heyn H, Nogales V, et al. 2017. The NCI-60 methylome and its integration into CellMiner. Cancer Res 77: 601-612. doi:10.1158/00085472.CAN-16-0655

Ricciuti B, Kravets S, Dahlberg SE, Umeton R, Albayrak A, Subegdjo SJ, Johnson BE, Nishino M, Sholl LM, Awad MM. 2019. Use of targeted next generation sequencing to characterize tumor mutational burden and efficacy 
B.J. Drapkin and C.M. Rudin

of immune checkpoint inhibition in small cell lung cancer. J Immunother Cancer 7: 87. doi:10.1186/s40425019-0572-6

Rittmeyer A, Barlesi F, Waterkamp D, Park K, Ciardiello F, von Pawel J, Gadgeel SM, Hida T, Kowalski DM, Dols MC, et al. 2017. Atezolizumab versus docetaxel in patients with previously treated non-small-cell lung cancer (OAK): a phase 3, open-label, multicentre randomised controlled trial. Lancet 389: 255-265. doi:10.1016/ S0140-6736(16)32517-X

Rizvi NA, Hellmann MD, Snyder A, Kvistborg P, Makarov V, Havel JJ, Lee W, Yuan J, Wong P, Ho TS, et al. 2015. Cancer immunology. Mutational landscape determines sensitivity to PD-1 blockade in non-small cell lung cancer. Science 348: 124-128. doi:10.1126/science.aaa1348

Romero OA, Torres-Diz M, Pros E, Savola S, Gomez A, Moran S, Saez C, Iwakawa R, Villanueva A, Montuenga LM, et al. 2014. MAX inactivation in small cell lung cancer disrupts MYC-SWI/SNF programs and is synthetic lethal with BRG1. Cancer Discov 4: 292-303. doi:10 .1158/2159-8290.CD-13-0799

Rossi A, Di Maio M, Chiodini P, Rudd RM, Okamoto H, Skarlos DV, Früh M, Qian W, Tamura T, Samantas E, et al. 2012. Carboplatin- or cisplatin-based chemotherapy in first-line treatment of small-cell lung cancer: the COCIS meta-analysis of individual patient data. J Clin Oncol 30: 1692-1698. doi:10.1200/JCO.2011.40.4905

Rudin CM, Hann CL, Garon EB, Ribeiro de Oliveira M, Bonomi PD, Camidge DR, Chu Q, Giaccone G, Khaira D, Ramalingam SS, et al. 2012a. Phase II study of singleagent navitoclax (ABT-263) and biomarker correlates in patients with relapsed small cell lung cancer. Clin Cancer Res 18: 3163-3169. doi:10.1158/1078-0432.CCR-11-3090

Rudin CM, Durinck S, Stawiski EW, Poirier JT, Modrusan Z, Shames DS, Bergbower EA, Guan Y, Shin J, Guillory J, et al. 2012b. Comprehensive genomic analysis identifies SOX2 as a frequently amplified gene in small-cell lung cancer. Nat Genet 44: 1111-1116. doi:10.1038/ng.2405

Rudin CM, Poirier JT, Byers LA, Dive C, Dowlati A, George J, Heymach JV, Johnson JE, Lehman JM, MacPherson D, et al. 2019. Molecular subtypes of small cell lung cancer: a synthesis of human and mouse model data. Nat Rev Cancer 19: 289-297. doi:10.1038/s41568-019-0133-9

Sandler A, Gray R, Perry MC, Brahmer J, Schiller JH, Dowlati A, Lilenbaum R, Johnson DH. 2006. Paclitaxel-carboplatin alone or with bevacizumab for non-small-cell lung cancer. N Engl J Med 355: 2542-2550. doi:10.1056/NEJ Moa061884

Saunders LR, Bankovich AJ, Anderson WC, Aujay MA, Bheddah S, Black K, Desai R, Escarpe PA, Hampl J, Laysang A, et al. 2015. A DLL3-targeted antibody-drug conjugate eradicates high-grade pulmonary neuroendocrine tumor-initiating cells in vivo. Sci Transl Med 7: 302ra136. doi:10.1126/scitranslmed.aac9459

Scagliotti GV, Parikh P, von Pawel J, Biesma B, Vansteenkiste J, Manegold C, Serwatowski P, Gatzemeier U, Digumarti R, Zukin M, et al. 2008. Phase III study comparing cisplatin plus gemcitabine with cisplatin plus pemetrexed in chemotherapy-naive patients with advanced-stage nonsmall-cell lung cancer. J Clin Oncol 26: 3543-3551. doi:10 $.1200 /$ JCO.2007.15.0375
Schaffer BE, Park KS, Yiu G, Conklin JF, Lin C, Burkhart DL, Karnezis AN, Sweet-Cordero EA, Sage J. 2010. Loss of p130 accelerates tumor development in a mouse model for human small-cell lung carcinoma. Cancer Res 70: 3877-3883. doi:10.1158/0008-5472.CAN-09-4228

Schultheis AM, Scheel AH, Ozretić L, George J, Thomas RK, Hagemann T, Zander T, Wolf J, Buettner R. 2015. PD-L1 expression in small cell neuroendocrine carcinomas. Eur J Cancer 51: 421-426. doi:10.1016/j.ejca.2014.12.006

Schwarz JK, Devoto SH, Smith EJ, Chellappan SP, Jakoi L, Nevins JR. 1993. Interactions of the 107 and Rb proteins with $\mathrm{E} 2 \mathrm{~F}$ during the cell proliferation response. $E M B O J$ 12: 1013-1020. doi:10.1002/j.1460-2075.1993.tb05742.x

Seftor RE, Hess AR, Seftor EA, Kirschmann DA, Hardy KM, Margaryan NV, Hendrix MJ. 2012. Tumor cell vasculogenic mimicry: from controversy to therapeutic promise. Am J Pathol 181: 1115-1125. doi:10.1016/j.ajpath.2012 .07 .013

Sen T, Rodriguez BL, Chen L, Corte CMD, Morikawa N, Fujimoto J, Cristea S, Nguyen T, Diao L, Li L, et al. 2019. Targeting DNA damage response promotes antitumor immunity through STING-mediated T-cell activation in small cell lung cancer. Cancer Discov 9: 646-661. doi:10.1158/2159-8290.CD-18-1020

Sequist LV, Waltman BA, Dias-Santagata D, Digumarthy S, Turke AB, Fidias P, Bergethon K, Shaw AT, Gettinger S, Cosper AK, et al. 2011. Genotypic and histological evolution of lung cancers acquiring resistance to EGFR inhibitors. Sci Transl Med 3: 75ra26. doi:10.1126/sci translmed.3002003

Shoemaker AR, Mitten MJ, Adickes J, Ackler S, Refici M, Ferguson D, Oleksijew A, O'Connor JM, Wang B, Frost DJ, et al. 2008. Activity of the Bcl-2 family inhibitor ABT263 in a panel of small cell lung cancer xenograft models. Clin Cancer Res 14: 3268-3277. doi:10.1158/1078-0432 .CCR-07-4622

Shtivelman E, Hensing T, Simon GR, Dennis PA, Otterson GA, Bueno R, Salgia R. 2014. Molecular pathways and therapeutic targets in lung cancer. Oncotarget 5: 13921433.

Silva M, Galeone C, Sverzellati N, Marchianò A, Calareso G, Sestini S, La Vecchia C, Sozzi G, Pelosi G, Pastorino U. 2016. Screening with low-dose computed tomography does not improve survival of small cell lung cancer. $J$ Thorac Oncol 11: 187-193. doi:10.1016/j.jtho.2015.10 .014

Smith BA, Balanis NG, Nanjundiah A, Sheu KM, Tsai BL, Zhang Q, Park JW, Thompson M, Huang J, Witte ON, et al. 2018. A human adult stem cell signature marks aggressive variants across epithelial cancers. Cell Rep 24: 33533366.e5. doi:10.1016/j.celrep.2018.08.062

Socinski MA, Bondarenko I, Karaseva NA, Makhson AM, Vynnychenko I, Okamoto I, Hon JK, Hirsh V, Bhar P, Zhang H, et al. 2012. Weekly nab-paclitaxel in combination with carboplatin versus solvent-based paclitaxel plus carboplatin as first-line therapy in patients with advanced non-small-cell lung cancer: final results of a phase III trial. J Clin Oncol 30: 2055-2062. doi:10.1200/JCO.2011.39 .5848

Socinski MA, Jotte RM, Cappuzzo F, Orlandi F, Stroyakovskiy D, Nogami N, Rodríguez-Abreu D, Moro-Sibilot D, Thomas CA, Barlesi F, et al. 2018. Atezolizumab for 
first-line treatment of metastatic nonsquamous NSCLC. $N$ Engl J Med 378: 2288-2301. doi:10.1056/NEJMoa 1716948

Soria JC, Ohe Y, Vansteenkiste J, Reungwetwattana T, Chewaskulyong B, Lee $\mathrm{KH}$, Dechaphunkul A, Imamura $\mathrm{F}$, Nogami N, Kurata T, et al. 2018. Osimertinib in untreated EGFR-mutated advanced non-small-cell lung cancer. $N$ Engl J Med 378: 113-125. doi:10.1056/NEJMoa1713137

Sos ML, Dietlein F, Peifer M, Schöttle J, Balke-Want H, Müller C, Koker M, Richters A, Heynck S, Malchers F, et al. 2012. A framework for identification of actionable cancer genome dependencies in small cell lung cancer. Proc Natl Acad Sci 109: 17034-17039. doi:10.1073/pnas 1207310109

Sousa FG, Matuo R, Tang SW, Rajapakse VN, Luna A, Sander C, Varma S, Simon PHG, Doroshow JH, Reinhold WC, et al. 2015. Alterations of DNA repair genes in the NCI-60 cell lines and their predictive value for anticancer drug activity. DNA Repair (Amst) 28: 107-115. doi:10 .1016/j.dnarep.2015.01.011

Sriuranpong V, Borges MW, Ravi RK, Arnold DR, Nelkin BD, Baylin SB, Ball DW. 2001. Notch signaling induces cell cycle arrest in small cell lung cancer cells. Cancer Res 61: 3200-3205.

Sriuranpong V, Borges MW, Strock CL, Nakakura EK, Watkins DN, Blaumueller CM, Nelkin BD, Ball DW. 2002 Notch signaling induces rapid degradation of achaetescute homolog 1. Mol Cell Biol 22: 3129-3139. doi:10 .1128/MCB.22.9.3129-3139.2002

Steffens CC, Elender C, Hutzschenreuter U, Dille S, Binninger A, Spring L, Jänicke M, Marschner N; TLK-Group (Tumour Registry Lung Cancer). 2019. Treatment and outcome of 432 patients with extensive-stage small cell lung cancer in first, second and third line-results from the prospective German TLK cohort study. Lung Cancer 130: 216-225. doi:10.1016/j.lungcan.2019.02.026

Stewart CA, Tong P, Cardnell RJ, Sen T, Li L, Gay CM, Masrorpour F, Fan Y, Bara RO, Feng Y, et al. 2017. Dynamic variations in epithelial-to-mesenchymal transition (EMT), ATM, and SLFN11 govern response to PARP inhibitors and cisplatin in small cell lung cancer. Oncotarget 8: 28575-28587.

Stewart CA, Gay CM, Xi Y, Sivajothi S, Sivakamasundari V, Fujimoto J, Bolisetty M, Hartsfield PM, Balasubramaniyan V, Chalishazar MD, et al. 2020. Single-cell analyses reveal increased intratumoral heterogeneity after the onset of therapy resistance in small-cell lung cancer. Nat Cancer. doi:10.1038/s43018-019-0020-z

Stiewe T, Theseling CC, Pützer BM. 2002. Transactivationdeficient $\Delta$ TA-p73 inhibits $\mathrm{p} 53$ by direct competition for DNA binding: implications for tumorigenesis. $J$ Biol Chem 277: 14177-14185. doi:10.1074/jbc.M200480200

Su Z, Wang Z, Ni X, Duan J, Gao Y, Zhuo M, Li R, Zhao J, Ma Q, Bai H, et al. 2019. Inferring the evolution and progression of small-cell lung cancer by single-cell sequencing of circulating tumor cells. Clin Cancer Res 25: 5049-5060. doi:10.1158/1078-0432.CCR-18-3571

Sun JM, Choi YL, Ji JH, Ahn JS, Kim KM, Han J, Ahn MJ, Park K. 2015. Small-cell lung cancer detection in neversmokers: clinical characteristics and multigene mutation profiling using targeted next-generation sequencing. Ann Oncol 26: 161-166. doi:10.1093/annonc/mdu504
Small-Cell Lung Cancer Translational Research

Sundaresan V, Lin VT, Liang F, Kaye FJ, Kawabata-Iwakawa R, Shiraishi K, Kohno T, Yokota J, Zhou L. 2017. Significantly mutated genes and regulatory pathways in SCLC-a meta-analysis. Cancer Genet 216-217: 20-28. doi:10 .1016/j.cancergen.2017.05.003

Sutherland KD, Proost N, Brouns I, Adriaensen D, Song JY, Berns A. 2011. Cell of origin of small cell lung cancer: inactivation of Trp53 and Rb1 in distinct cell types of adult mouse lung. Cancer Cell 19: 754-764. doi:10 1016/j.ccr.2011.04.019

Tan HL, Sood A, Rahimi HA, Wang W, Gupta N, Hicks J, Mosier S, Gocke CD, Epstein JI, Netto GJ, et al. 2014. Rb loss is characteristic of prostatic small cell neuroendocrine carcinoma. Clin Cancer Res 20: 890-903. doi:10.1158/ 1078-0432.CCR-13-1982

Tang SW, Thomas A, Murai J, Trepel JB, Bates SE, Rajapakse VN, Pommier Y. 2018. Overcoming resistance to DNAtargeted agents by epigenetic activation of Schlafen 11 (SLFN11) expression with class I histone deacetylase inhibitors. Clin Cancer Res 24: 1944-1953. doi:10.1158/ 1078-0432.CCR-17-0443

Tata PR, Rajagopal J. 2017. Plasticity in the lung: making and breaking cell identity. Development 144: 755-766. doi:10 $.1242 /$ dev. 143784

Tata PR, Mou H, Pardo-Saganta A, Zhao R, Prabhu M, Law BM, Vinarsky V, Cho JL, Breton S, Sahay A, et al. 2013. Dedifferentiation of committed epithelial cells into stem cells in vivo. Nature 503: 218-223. doi:10.1038/nature 12777

Thomas A, Pattanayak P, Szabo E, Pinsky P. 2018. Characteristics and outcomes of small cell lung cancer detected by CT screening. Chest 154: 1284-1290. doi:10.1016/j .chest.2018.07.029

Thomas A, Vilimas R, Trindade C, Erwin-Cohen R, Roper N, Xi L, Krishnasamy V, Levy E, Mammen A, Nichols S, et al. 2019. Durvalumab in combination with olaparib in patients with relapsed SCLC: results from a phase II study. J Thorac Oncol 14: 1447-1457. doi:10.1016/j.jtho.2019.04 .026

Tivol EA, Borriello F, Schweitzer AN, Lynch WP, Bluestone JA, Sharpe AH. 1995. Loss of CTLA-4 leads to massive lymphoproliferation and fatal multiorgan tissue destruction, revealing a critical negative regulatory role of CTLA4. Immunity 3: 541-547. doi:10.1016/1074-7613(95) 90125-6

Traversari C, Meazza R, Coppolecchia M, Basso S, Verrecchia A, van der Bruggen P, Ardizzoni A, Gaggero A, Ferrini S. 1997. IFN- $\gamma$ gene transfer restores HLA-class I expression and MAGE-3 antigen presentation to CTL in HLA-deficient small cell lung cancer. Gene Ther 4: 1029-1035. doi:10.1038/sj.gt.3300489

Tseng SY, Otsuji M, Gorski K, Huang X, Slansky JE, Pai SI, Shalabi A, Shin T, Pardoll DM, Tsuchiya H. 2001. B7-DC, a new dendritic cell molecule with potent costimulatory properties for T cells. J Exp Med 193: 839-846. doi:10 $.1084 /$ jem.193.7.839

Turner N, Tutt A, Ashworth A. 2004. Hallmarks of "BRCAness" in sporadic cancers. Nat Rev Cancer 4: 814-819. doi:10.1038/nrc1457

Tutt A, Robson M, Garber JE, Domchek SM, Audeh MW, Weitzel JN, Friedlander M, Arun B, Loman N, Schmutzler RK, et al. 2010. Oral poly(ADP-ribose) poly- 
merase inhibitor olaparib in patients with BRCA1 or BRCA2 mutations and advanced breast cancer: a proofof-concept trial. Lancet 376: 235-244. doi:10.1016/ S0140-6736(10)60892-6

Tzelepi V, Zhang J, Lu JF, Kleb B, Wu G, Wan X, Hoang A, Efstathiou E, Sircar K, Navone NM, et al. 2012. Modeling a lethal prostate cancer variant with small-cell carcinoma features. Clin Cancer Res 18: 666-677. doi:10.1158/10780432.CCR-11-1867

Umemura S, Mimaki S, Makinoshima H, Tada S, Ishii G, Ohmatsu H, Niho S, Yoh K, Matsumoto S, Takahashi A, et al. 2014. Therapeutic priority of the PI3 K/AKT/mTOR pathway in small cell lung cancers as revealed by a comprehensive genomic analysis. J Thorac Oncol 9: 13241331. doi:10.1097/JTO.0000000000000250

van Zandwijk N, Groen HJ, Postmus PE, Burghouts JT, ten Velde GP, Ardizzoni A, Smith IE, Baas P, Sahmoud T, Kirkpatrick A, et al. 1997. Role of recombinant interferon- $\gamma$ maintenance in responding patients with small cell lung cancer. A randomised phase III study of the EORTC Lung Cancer Cooperative Group. Eur J Cancer 33: 17591766. doi:10.1016/S0959-8049(97)00174-3

Varghese AM, Zakowski MF, Yu HA, Won HH, Riely GJ, Krug LM, Kris MG, Rekhtman N, Ladanyi M, Wang L, et al. 2014. Small-cell lung cancers in patients who never smoked cigarettes. J Thorac Oncol 9: 892-896. doi:10 $.1097 /$ JTO.0000000000000142

Vélez-Cruz R, Manickavinayaham S, Biswas AK, Clary RW, Premkumar T, Cole F, Johnson DG. 2016. RB localizes to DNA double-strand breaks and promotes DNA end resection and homologous recombination through the recruitment of BRG1. Genes Dev 30: 2500-2512. doi:10 $.1101 /$ gad.288282.116

Wael H, Yoshida R, Kudoh S, Hasegawa K, Niimori-Kita K, Ito T. 2014. Notch1 signaling controls cell proliferation, apoptosis and differentiation in lung carcinoma. Lung Cancer 85: 131-140. doi:10.1016/j.lungcan.2014.05.001

Wagner AH, Devarakonda S, Skidmore ZL, Krysiak K, Ramu A, Trani L, Kunisaki J, Masood A, Wagar SN, Spies NC, et al. 2018. Recurrent WNT pathway alterations are frequent in relapsed small cell lung cancer. Nat Commun 9: 3787. doi:10.1038/s41467-018-06162-9

Walter DM, Yates TJ, Ruiz-Torres M, Kim-Kiselak C, Gudiel AA, Deshpande C, Wang WZ, Cicchini M, Stokes KL, Tobias JW, et al. 2019. RB constrains lineage fidelity and multiple stages of tumour progression and metastasis. Nature 569: 423-427. doi:10.1038/s41586-019$1172-9$

Wang W, Hodkinson P, McLaren F, Mackean MJ, Williams L, Howie SEM, Wallace WAH, Sethi T. 2013. Histologic assessment of tumor-associated $\mathrm{CD} 45^{+}$cell numbers is an independent predictor of prognosis in small cell lung cancer. Chest 143: 146-151. doi:10.1378/chest.12-0681

Waterhouse P, Penninger JM, Timms E, Wakeham A, Shahinian A, Lee KP, Thompson CB, Griesser H, Mak TW. 1995. Lymphoproliferative disorders with early lethality in mice deficient in Ctla-4. Science 270: 985-988. doi:10 $.1126 /$ science. 270.5238 .985

Williamson SC, Metcalf RL, Trapani F, Mohan S, Antonello J, Abbott B, Leong HS, Chester CP, Simms N, Polanski R, et al. 2016. Vasculogenic mimicry in small cell lung cancer. Nat Commun 7: 13322. doi:10.1038/ncomms13322
Woll P, Gaunt P, Steele N, Ahmed S, Mulatero C, Shah R, Danson S, Hodgkinson E, James K, Watkins B, et al. 2017. STOMP: a UK National cancer research network randomised, double blind, multicentre phase II trial of olaparib as maintenance therapy in SCLC. J Thoracic Oncol 12: S704-S7S5. doi:10.1016/j.jtho.2016.11.926

Wu N, Jia D, Ibrahim AH, Bachurski CJ, Gronostajski RM, MacPherson D. 2016. NFIB overexpression cooperates with $R b / p 53$ deletion to promote small cell lung cancer. Oncotarget 7: 57514-57524.

Yang D, Denny SK, Greenside PG, Chaikovsky AC, Brady JJ, Ouadah Y, Granja JM, Jahchan NS, Lim JS, Kwok S, et al. 2018. Intertumoral heterogeneity in SCLC is influenced by the cell type of origin. Cancer Discov 8: 1316-1331. doi:10.1158/2159-8290.CD-17-0987

Yao E, Lin C, Wu Q, Zhang K, Song H, Chuang PT. 2018. Notch signaling controls transdifferentiation of pulmonary neuroendocrine cells in response to lung injury. Stem Cells 36: 377-391. doi:10.1002/stem.2744

Yarchoan M, Hopkins A, Jaffee EM. 2017. Tumor mutational burden and response rate to PD-1 inhibition. $N$ Engl J Med 377: 2500-2501. doi:10.1056/NEJMc1713444

Yasunami M, Suzuki K, Maruyama H, Kawakami H, Nagai Y, Hagiwara M, Ohkubo H. 1996. Molecular cloning and characterization of a cDNA encoding a novel basic helixloop-helix protein structurally related to Neuro-D/BHF1. Biochem Biophys Res Commun 220: 754-758. doi:10 $.1006 /$ bbrc. 1996.0476

Yazawa T, Kamma H, Fujiwara M, Matsui M, Horiguchi H, Satoh H, Fujimoto M, Yokoyama K, Ogata T. 1999. Lack of class II transactivator causes severe deficiency of HLA-DR expression in small cell lung cancer. J Pathol 187: 191-199. doi:10.1002/(SICI)1096-9896(199901) 187:2<191::AID-PATH206>3.0.CO;2-3

Yu M, Stott S, Toner M, Maheswaran S, Haber DA. 2011. Circulating tumor cells: approaches to isolation and characterization. J Cell Biol 192: 373-382. doi:10.1083/jcb .201010021

Yu HA, Arcila ME, Rekhtman N, Sima CS, Zakowski MF, Pao W, Kris MG, Miller VA, Ladanyi M, Riely GJ. 2013a. Analysis of tumor specimens at the time of acquired resistance to EGFR-TKI therapy in 155 patients with EGFR-mutant lung cancers. Clin Cancer Res 19: $2240-$ 2247. doi:10.1158/1078-0432.CCR-12-2246

Yu M, Bardia A, Wittner BS, Stott SL, Smas ME, Ting DT, Isakoff SJ, Ciciliano JC, Wells MN, Shah AM, et al. 2013b. Circulating breast tumor cells exhibit dynamic changes in epithelial and mesenchymal composition. Science 339: 580-584. doi:10.1126/science.1228522

Yu M, Bardia A, Aceto N, Bersani F, Madden MW, Donaldson MC, Desai R, Zhu H, Comaills V, Zheng Z, et al. 2014. Cancer therapy. Ex vivo culture of circulating breast tumor cells for individualized testing of drug susceptibility. Science 345: 216-220. doi:10.1126/science .1253533

Yu H, Batenchuk C, Badzio A, Boyle TA, Czapiewski P, Chan DC, Lu X, Gao D, Ellison K, Kowalewski AA, et al. 2017. PD-L1 expression by two complementary diagnostic assays and mRNA in situ hybridization in small cell lung cancer. J Thorac Oncol 12: 110-120. doi:10.1016/j.jtho .2016 .09 .002 
Small-Cell Lung Cancer Translational Research

Zhang W, Girard L, Zhang YA, Haruki T, Papari-Zareei M, Stastny V, Ghayee HK, Pacak K, Oliver TG, Minna JD, et al. 2018. Small cell lung cancer tumors and preclinical models display heterogeneity of neuroendocrine phenotypes. Transl Lung Cancer Res 7: 32-49. doi:10.21037/tlcr .2018 .02 .02

Zhang H, Christensen CL, Dries R, Oser MG, Deng J, Diskin B, Li F, Pan Y, Zhang X, Yin Y, et al. 2020. CDK7 Inhibi- tion potentiates genome instability triggering anti-tumor immunity in small cell lung cancer. Cancer Cell 37:37-54. e9. doi:10.1016/j.ccell.2019.11.003

Zoppoli G, Regairaz M, Leo E, Reinhold WC, Varma S, Ballestrero A, Doroshow JH, Pommier Y. 2012. Putative DNA/RNA helicase Schlafen-11 (SLFN11) sensitizes cancer cells to DNA-damaging agents. Proc Natl Acad Sci 109: 15030-15035. doi:10.1073/pnas.1205943109 


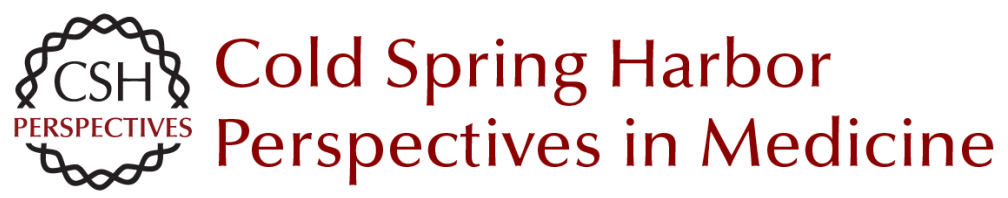

\section{Advances in Small-Cell Lung Cancer (SCLC) Translational Research}

Benjamin J. Drapkin and Charles M. Rudin

Cold Spring Harb Perspect Med 2021; doi: 10.1101/cshperspect.a038240 originally published online June 8, 2020

\section{Subject Collection Lung Cancer: Disease Biology and Its Potential for Clinical Translation}

Tumor Immunology and Immunotherapy of Non-Small-Cell Lung Cancer Tina Cascone, Jared Fradette, Monika Pradhan, et al.

Molecular Pathology of Lung Cancer James J. Saller and Theresa A. Boyle

Preclinical Models for the Study of Lung Cancer Pathogenesis and Therapy Development Anna Arnal-Estapé, Giorgia Foggetti, Jacqueline $H$. Starrett, et al.

Radiation Therapy in Non-Small-Cell Lung Cancer Michael Dohopolski, Sujana Gottumukkala, Daniel Gomez, et al.

Application of Radiomics and Artificial Intelligence for Lung Cancer Precision Medicine Ilke Tunali, Robert J. Gillies and Matthew B. Schabath

Advances in Small-Cell Lung Cancer (SCLC) Translational Research Benjamin J. Drapkin and Charles M. Rudin
Lung Cancer Stem Cells and Their Clinical Implications

Samuel P. Rowbotham, Mounika U.L. Goruganthu, Rajeswara R. Arasada, et al.

Lung Cancer Computational Biology and Resources Ling Cai, Guanghua Xiao, David Gerber, et al.

Metabolic Phenotypes, Dependencies, and Adaptation in Lung Cancer Gina M. DeNicola and David B. Shackelford

Early Diagnosis and Screening for Lung Cancer Humam Kadara, Linh M. Tran, Bin Liu, et al.

Targeting Epigenetics in Lung Cancer Yvonne L. Chao and Chad V. Pecot

For additional articles in this collection, see http://perspectivesinmedicine.cshlp.org/cgi/collection/ 